Jeronimo de AlenCAR NogueIRA

\title{
Mutação pontual do códon 249 do TP53 no carcinoma hepatocelular
}

Dissertação apresentada à Faculdade de Medicina da Universidade de São Paulo para obtenção do título de Mestre em Ciências

Área de concentração: Gastroenterologia Clínica Orientadora: Profa. Dra. Suzane Kioko Ono-Nita

São Paulo 


\section{Dados Internacionais de Catalogação na Publicação (CIP)}

Preparada pela Biblioteca da

Faculdade de Medicina da Universidade de São Paulo

@reprodução autorizada pelo autor

Nogueira, Jeronimo de Alencar

Mutação pontual do códon 249 do TP53 no carcinoma hepatocelular /

Jeronimo de Alencar Nogueira. -- São Paulo, 2007.

Dissertação(mestrado)--Faculdade de Medicina da Universidade de São Paulo. Departamento de Gastroenterologia.

Área de concentração: Gastroenterologia Clínica.

Orientadora: Suzane Kioko Ono-Nita.

Descritores: 1.Mutação 2.Genes p53 3.Carcinoma hepatocelular 4.Aflatoxina B1

USP/FM/SBD-357/07 


\section{DEDICATÓRIA}


Aos meus pais Evaldo e Ana pelo amor e incentivo.

Ao meu irmão Igor pela amizade ao longo de todos estes anos.

Aos meus avós Gerardo e Eva pelo imensurável carinho. 
AGRADECIMENTOS 
Agradeço a todas as pessoas que de alguma forma participaram não apenas do meu trabalho, mas também da minha vida neste período. A todos aqueles que comemoraram comigo os sucessos e me apoiaram nos inúmeros momentos difíceis que enfrentamos.

À Profa. Dra. Suzane Kioko Ono-Nita e Dr. Marcelo Eidi Nita pela valiosa orientação, participação e incentivo durante todo o processo de execução do meu trabalho e aprendizado.

Ao Prof. Dr. Flair José Carrilho, excelente mentor e chefe. Seu comprometimento com o grupo e com a ciência sempre foi motivo de minha mais profunda admiração.

Ao Professor Dr. Venâncio Avancini Ferreira Alves por compartilhar suas inestimáveis idéias e experiência, sem as quais a execução do trabalho seria inviável.

Meus mais profundos agradecimentos aos meus colegas Eliane Pereira do Carmo, Helena Scavone Paschoale, Marcelo Moreira Tavares de Souza, Fernanda Barbosa, pela constante ajuda prestada no desenvolvimento de todos os projetos de pesquisa nos quais eu tomei parte.

Ao Dr. Cristovan Scapulatempo Neto e Dr. Evandro Sobroza Mello, não apenas pelo auxilio na obtenção e seleção dos casos, mas também pela constante participação na pesquisa.

À Profa. Dra. Dulce Guarita e Dra. Denise Cerqueira Paranaguá Vezozzo pelo apoio e incentivo.

Aos funcionários do Departamento de Anatomia Patológica, pela ajuda na aquisição das amostras que compuseram meu trabalho. 
À Alves de Queiroz Family Fund for Research e a Fundação de Amparo a Pesquisa do Estado de São Paulo, pelo auxílio financeiro. 
Esta dissertação está de acordo com as seguintes normas, em vigor no momento da publicação:

Referências: adaptado de International Committee of Medical Journals Editors (Vancouver)

Universidade de São Paulo. Faculdade de Medicina. Serviço de Biblioteca e Documentação. Guia de apresentação de dissertações, teses e monografias. Elaborado por Anneliese Carneiro da Cunha, Maria julia de A.L. Freddi, Maria F. Crestana, Marinalva de Souza Aragão, Suely Campos Cardoso, Valéria Vilhena, $2^{a}$ ed. São Paulo: Serviço de Biblioteca e Documentação; 2005.

Abreviaturas dos títulos dos periódicos de acordo com List of Journals Indexed in Index Medicus 
SUMÁRIO 


\section{LISTA DE ABREVIAÇÃO \\ LISTA DE FIGURAS \\ LISTA DE TABELAS \\ RESUMO \\ SUMMARY}

1 INTRODUÇÃO

1.1 Carcinoma hepatocelular ............................................................ 2

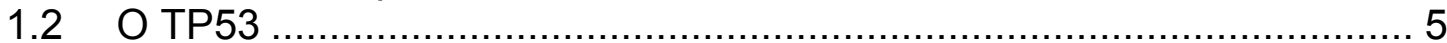

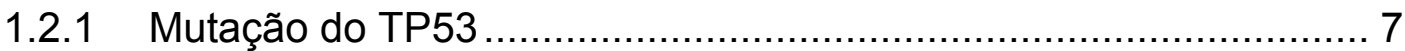

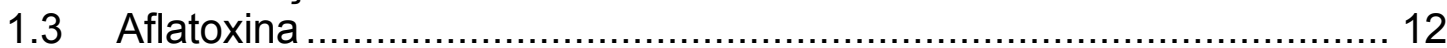

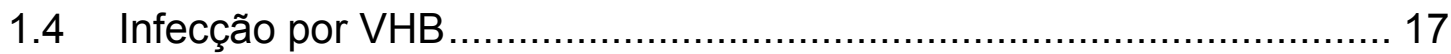

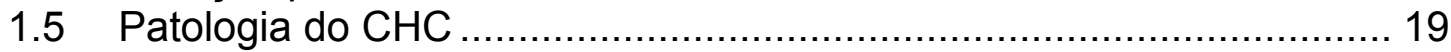

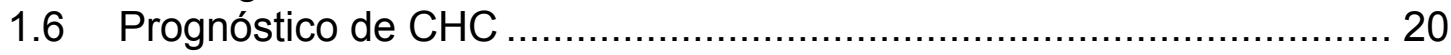

1.7 Potenciais Impactos do Estudo..................................................... 21

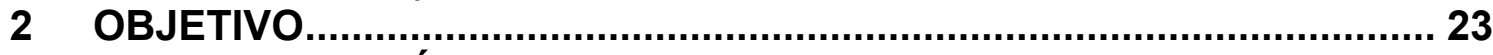

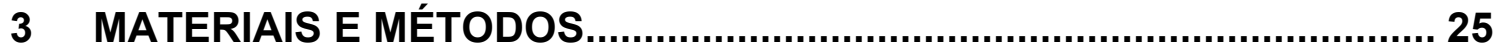

3.1 Seleção dos pacientes e das amostras a serem estudadas ................ 26

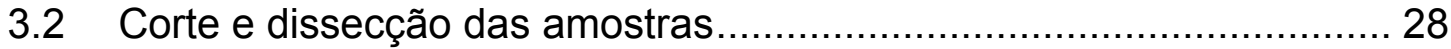

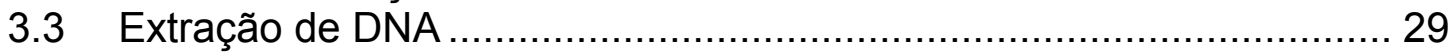

3.4 Análise da presença da mutação........................................................ 30

3.5 Detecção do DNA do VHB nas amostras ….................................... 35

3.6 Obtenção de dados clínicos anátomo-patológicos ............................... 35

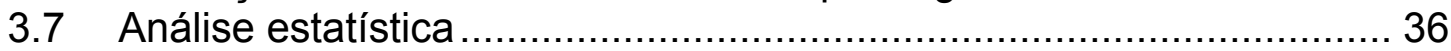

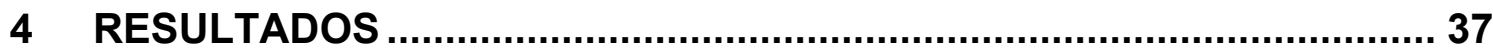

4.1 Padronização da Extração de DNA …………................................. 38

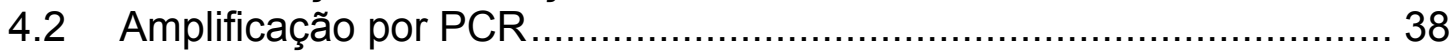

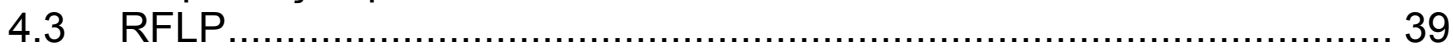

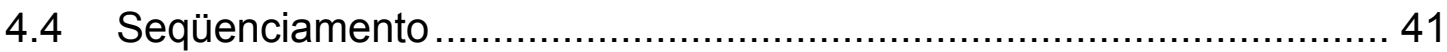

4.5 Presença de VHB ................................................................ 42

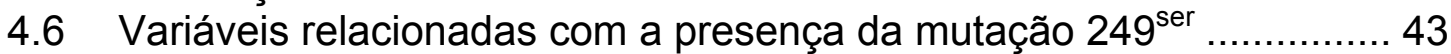

5 DISCUSSÃO ................................................................................... 47

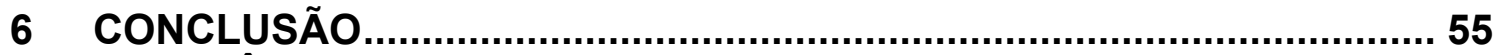

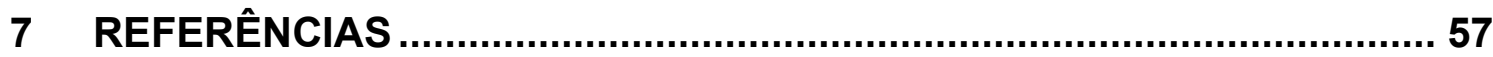

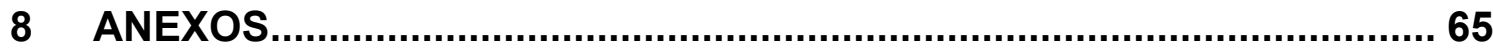




\section{LISTAS}




\section{LISTA DE ABREVIAÇÃO}

$\mu \mathrm{g}:$ Microgramas

$\mu \mathrm{M}$ : Micromolar

A: Adenina

AFB1: Aflatoxina B1

AFM1: Aflatoxina M1

Arg: Arginina

C: Citosina

CDK: Quinase Dependente de Ciclina

CHC: Carcinoma hepatocelular

CICAP: Centro de Imunohistoquímica, Citopatologia e Anatomia Patológica

Cyp450: Citocromo p-450

DAP: Departamento de Anatomia Patológica

DNA: Ácido desoxirribonucléico

dNTP: Deoxinucleotídeos

FMUSP: Faculdade de Medicina da Universidade de São Paulo

G: Guanina

GST: Glutationa S-transferase

HC: Hospital das Clínicas

IARC: International Association for Research of Cancer

IC: Intervalo de confiança

INCA: Instituto Nacional do Câncer

M: Molar

MGB: Minor Groove Binder

$\mathrm{mM}$ : Milimolar

ng: Nanogramas

nM: Nanomolar

${ }^{\circ} \mathrm{C}$ : Graus Celcius

OMS: Organização Mundial de Saúde

OR: Odds ratio

$\mathrm{pb}$ : pares de base

PCR: Reação em cadeia da polimerase

pM: Pico molar

ppb: Partes por bilhão

RFLP: Restriction Fragment Length Polymorphism

SAME: Serviço de Arquivo Médico e Estatístico

Ser: Serina

SNP: Polimorfismo de um único nucleotídeo (Single Nucleotide

Polymorphism)

SVO: Sistema de Verificação de Óbito

T: Timina

TAE: Tris Acetato EDTA

TBE: Tris Borato EDTA

VHB: Vírus da Hepatite B

VHC: Vírus da Hepatite C 


\section{LISTA DE FIGURAS}

Figura 01: Índice de mortalidade por $\mathrm{CHC}$ no mundo. Índice relativo a 100.000 indivíduos

Figura 02: (A) Distribuição dos exons no gene TP53. (B) Distribuição dos domínios da $\mathrm{p} 53$, os números entre parênteses representam os aminoácidos correspondentes a cada subunidade.

Figura 03: Freqüência de mutação do TP53 em tumores de diferentes órgãos.

Figura 04: (A) freqüência de Mutações pontuais no TP53 vs Hot-Spot, levando em conta todos os tipos de tumor. (B) freqüência de Mutações pontuais no TP53 vs Hot-Spot apenas no $\mathrm{CHC}$.

Figura 05: A via metabólica da aflatoxina no organismo............................... 15

Figura 06: Microscopia óptica de cortes histológicos de $\mathrm{CHC}$ corados com $\mathrm{HE}$, aumento de 400x, representando os diferentes graus do CHC. No sentido horário: grau 1, grau 2, grau 3 e grau 4

Figura 07: Fluxograma da seleção dos casos............................................ 27

Figura 08: Esquema demonstrando a restrição do fragmento de PCR referente ao exon 7 do TP53. O fragmento possui 4 sítios de restrição para Haelll. Amostras com codon 249 normal irão formar 5 fragmentos de $92,66,37,30$ e $10 \mathrm{pb}$ enquanto amostras mutadas se clivarão em 158, 37, 30 e $10 \mathrm{pb}$

Figura 09: Corrida em gel de agarose 1,5\% TAE de produtos de PCR para o exon 7 do TP53

Figura 10: Restrição enzimática dos fragmentos de PCR. O fragmento de $158 \mathrm{pb}$ indica a presença de mutação do códon 249

Figura 11: Seqüenciamento do exon 7 do TP53: Circulado em vermelho está o códon 249, acima está representada uma amostra $249^{\text {Ser }}$, abaixo uma amostra sem mutação neste códon.

Figura 12: Amplificação por PCR em tempo real da diluição seriada do plasmídeo contendo todo o genoma do VHB. A menor concentração detectável neste método foi de 5 cópias por reação, representando a diluição mais a direita.

Figura 13: Amplificação por PCR em tempo real do DNA do VHB por PCR em tempo real, determinando a presença do DNA viral nos hepatócitos.

Figura 15: Comparação entre DNA extraído de parafina $(P)$ e de sangue periférico (SP) armazenado a $-20^{\circ} \mathrm{C}$. O marcador de peso molecular e de concentração utilizado foi o Low Mass Ladder (LM) 


\section{LISTA DE TABELAS}

Tabela 1: Freqüência da mutação do códon 249 e em outros pontos do TP53 em casos de CHC em áreas com diferentes níveis de exposição a aflatoxina......

Tabela 2: Associação entre AFB1 e $249^{\text {Ser }}$ segundo os critérios de

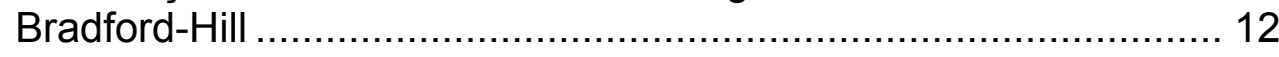

Tabela 3: Quantidade de Aflatoxina permitida ........................................ 17

Tabela 4: Análise de Pearson chi2 correlacionando presença da mutação e grau de diferenciação tumoral: Pearson chi2(3) = 7,6567, $p=0,054$.

Tabela 5: Associação entre tamanho de tumor e presença da mutação ....... 44

Tabela 6: Análise multivariada dos fatores que possuem relação com a presença da mutação 249Ser. 
RESUMO 
Nogueira JA. Mutação pontual do códon 249 do TP53 no carcinoma hepatocelular [dissertação]. São Paulo: Faculdade de Medicina, Universidade de São Paulo; 2007. 72p.

Mutação $249^{\text {Ser }}$ no TP53 no Carcinoma Hepatocelular (CHC), frequente em países da África e Ásia, é uma evidência molecular de exposição à aflatoxina. O objetivo deste estudo é analisar a freqüência de $249^{\text {Ser }}$ em 74 amostras de CHC no Brasil. A mutação foi analisada por RFLP e sequenciamento. A presença de vírus da hepatite $\mathrm{B}(\mathrm{VHB})$ foi analisada por PCR em tempo real. $249^{\text {Ser }}$ foi encontrada em 13/74 (28\%) e VHB em 13/74 (16\%). A mutação foi encontrada em maior freqüência em tumores indiferenciados $(\mathrm{OR}=2,415, \mathrm{IC}=1,001-5,824)$. $\mathrm{O}$ tamanho médio de tumores com $249^{\mathrm{Ser}}$ foi de $9,4 \mathrm{~cm}$ contra $5,5 \mathrm{~cm}$ de amostras sem a mutação $(p=0,012)$. Não foi encontrada relação entre $\mathrm{VHB}$ e $249^{\text {Ser }}$. Os resultados indicam que $249^{\text {Ser }}$ é um fator importante na carcinogênese do $\mathrm{CHC}$ no Brasil sendo associada à uma forma maior e menos diferenciada de tumor.

Descritores: 1. Mutação; 2.Genes, p53; 3. Carcinoma hepatocelular; 4. Aflatoxina B1. 
Nogueira JA. Mutation of TP53 codon 249 in the hepatocellular carcinoma [dissertation]. São Paulo: "Faculdade de Medicina, Universidade de São Paulo"; 2007. 72p.

TP53 $249^{\text {Ser }}$ mutation has been proved a molecular evidence for aflatoxinrelated Hepatocellular Carcinoma ( $\mathrm{HCC})$ and is frequent in Africa and Asia. The aim of our study was to analyze the frequency of $249^{\text {Ser }}$ mutation in HCC from Brazil. We studied 74 samples of paraffin embedded HCC. $249^{\text {Ser }}$ mutation was analyzed by RFLP and sequencing. Presence of HBV DNA was determined by Real-Time PCR. $249^{\text {Ser }}$ was found in $21 / 74$ (28\%) samples while HBV DNA was found in 13/74 (16\%). Poorly differentiated $\mathrm{HCC}$ was more likely to have $249^{\mathrm{Ser}}$ mutation $(\mathrm{OR}=2.415, \mathrm{IC}=1.001-$ 5.824). The mean tumor size of $249^{\text {Ser }} \mathrm{HCC}$ was $9.4 \mathrm{~cm}$ versus $5.5 \mathrm{~cm}$ on wild type $(p=0.012)$. HBV DNA was not related with $249^{\text {Ser }}$. Results indicate that $249^{\text {Ser }}$ is an important factor of HCC carcinogenesis in Brazil and is associated with large and poorly differentiated tumors.

Descriptors: 1. Mutation; 2. Genes, p53; 3. Hepatocellular Carcinoma; 4. Aflatoxin B1. 


\subsection{Carcinoma hepatocelular}

O câncer primário de fígado é o quinto tipo mais comum de câncer no mundo e a terceira maior causa de morte por câncer. O Carcinoma HepatoCelular ( $\mathrm{CHC})$ é responsável por aproximadamente $90 \%$ dos casos de câncer de fígado [1].

Segundo dados do INCA (Instituto Nacional de Câncer), o câncer hepático e das vias biliares ocupa a sétima posição no caso de óbitos por câncer no Brasil; sendo que, dentre estes tipos de tumores, o CHC é responsável por $80 \%$ dos casos.

São diversos os fatores capazes de levar ao surgimento de lesões prémalignas que podem culminar na evolução para um quadro neoplásico. Dentre eles os mais comuns são a infecção pelos vírus da Hepatite B ou C (VHB e VHC) e a ingestão de álcool e micotoxinas como a aflatoxina, presente em alimentos. Tais eventos acarretam na alteração de expressão de genes envolvidos na regulação do ciclo celular, levando à neoplasia [2]

O maior fator de risco para o desenvolvimento de $\mathrm{CHC}$ é a presença de cirrose hepática [3] . No Ambulatório de Hepatologia do Hospital das Clínicas da FMUSP, foi observado que $16 \%$ dos pacientes cirróticos atendidos vieram a desenvolver o carcinoma (dados não publicados).

É importante salientar que o desenvolvimento do $\mathrm{CHC}$ está intimamente vinculado a fatores ambientais e sócio-econômicos [4]. Desta forma, podem-se observar variações não só na incidência, mas também nas diferentes vias 
moleculares relacionadas à carcinogênese hepática em diferentes regiões geográficas. Por exemplo: mutações pontuais no gene do p53 são comuns em pacientes acometidos por $\mathrm{CHC}$ em regiões da China e da África, porém, em países europeus ou norte-americanos este evento é mais raro $[5,6]$. Da mesma forma que em países com alta incidência de VHB e aflatoxina, onde a infecção viral é adquirida em estágios precoces da vida e o $\mathrm{CHC}$ é desenvolvido em fígado não cirrótico, é observado com uma maior freqüência [3]. Por outro lado, em países desenvolvidos (onde a incidência deste tipo de tumor é menor), o surgimento de $\mathrm{CHC}$ está relacionado principalmente ao alcoolismo [7].

Outro fator etiológico do $\mathrm{CHC}$ que vem sendo discutido é a infecção viral associada à ingestão de álcool. O álcool pode ter um efeito sinérgico à infecção por VHB e VHC quanto ao risco de desenvolvimento do $\mathrm{CHC}$ [8]. Entretanto, um consumo de álcool moderado não foi associado à fibrose hepática em pacientes infectados com VHC [9].

Regiões como o sul da Europa podem ser exemplos da interação entre múltiplos fatores ambientais na carcinogênese hepática. Nestas regiões os dados de pesquisas sugerem um efeito sinérgico entre infecção por VHB, HCV e ingestão de álcool para o surgimento do CHC [10].

Mais de $80 \%$ dos casos de $\mathrm{CHC}$ ocorrem na região da África SubSaariana ou no leste asiático, sendo que apenas a China possui $50 \%$ dos casos de $\mathrm{CHC}$ do mundo [11, 12]. A distribuição dos casos de CHC no mundo está descrita na figura 01. 


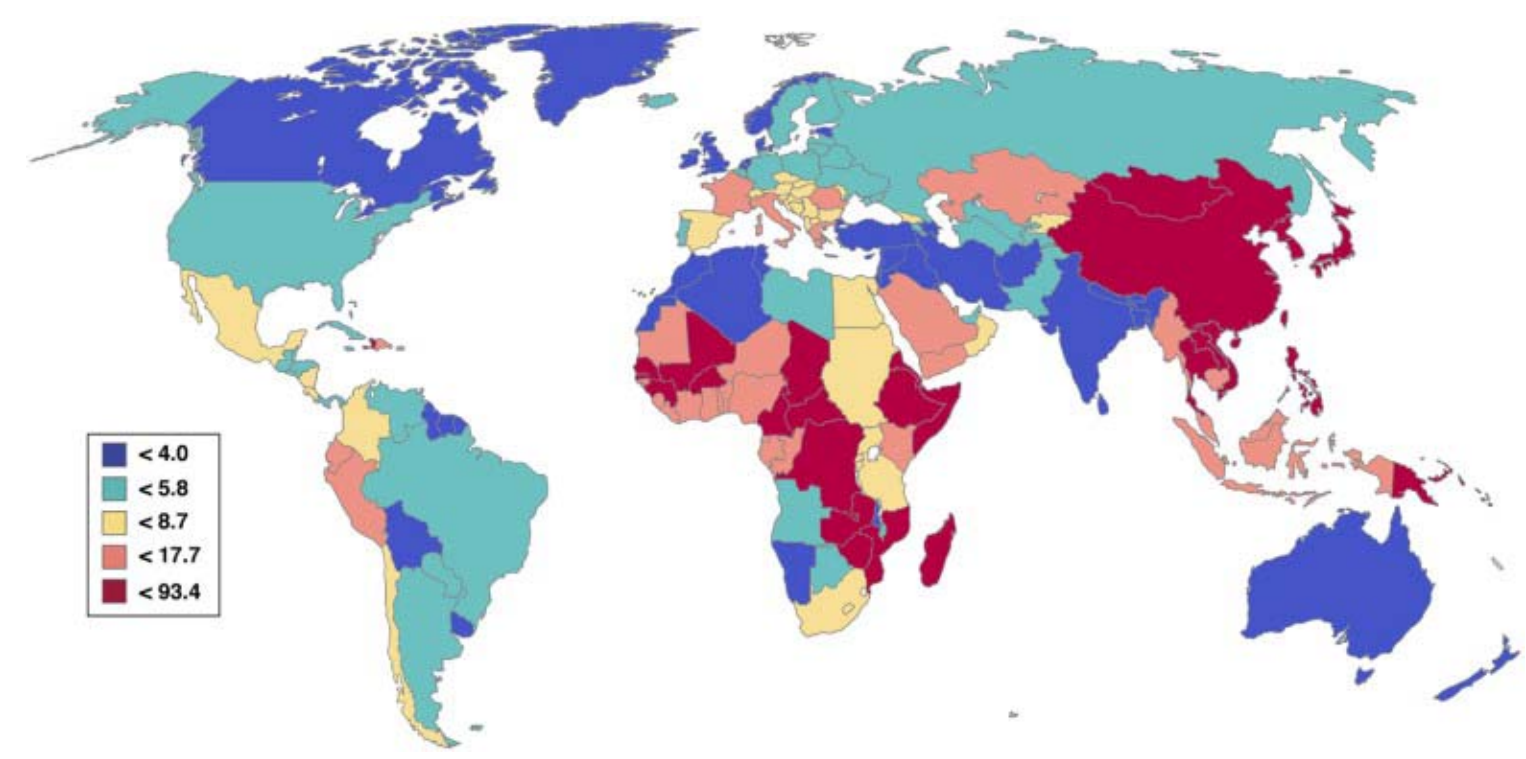

Figura 01: Índice de mortalidade por CHC no mundo. Índice relativo a 100.000 indivíduos

Fonte: El-Serag, 2007.

Apesar dos Estados Unidos serem uma região de baixa incidência de $\mathrm{CHC}$, este tipo de tumor é a causa de morte relacionada a câncer que mais cresce. Sua incidência dobrou entre 1985 e 2002. Este aumento está relacionado com novos casos de VHC $[11,13,14]$.

Foi demonstrado em estudos recentes que a cafeína possui uma ação hepatoprotetora, podendo inclusive prevenir o surgimento do $\mathrm{CHC}$. Em um estudo caso-controle realizado na Itália e na Grécia, observou-se um efeito benéfico da ingestão de café, diminuindo o risco de $\mathrm{CHC}$ [15]. Os mesmos resultados foram observados em uma população japonesa [16, 17]. 


\subsection{TP53}

O TP53, localizado no cromossomo 17p13.1 [18], é um gene supressor de tumor que possui 11 exons e codifica a proteína p53 constituída por 393 aminoácidos. Sua estrutura está representada na Figura 2.

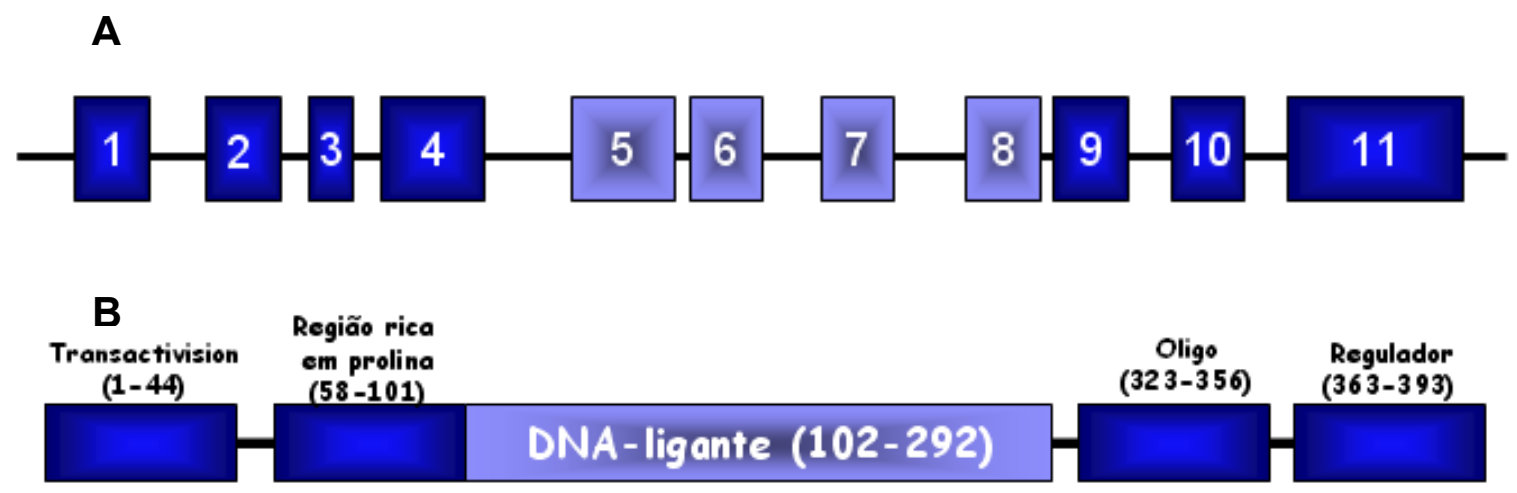

Figura 2: (A) Distribuição dos exons no gene TP53. (B) Distribuição dos domínios da p53, os números entre parênteses representam os aminoácidos correspondentes a cada subunidade.

Fonte: Adaptado do IARC TP53 Database, 2006

A p53 é uma proteína nuclear conhecida como sendo a "guardiã" do genoma. Sua função é impedir a proliferação de células que sofreram alguma alteração em seu material genético. Em condições fisiológicas esta proteína apresenta uma meia vida relativamente curta (aproximadamente 20 minutos).

O principal mecanismo de ação da p53 é como fator de transcrição, que poderá culminar em dois eventos: (1) parada do ciclo celular e eventual reparação do DNA e (2) apoptose.

Parada do ciclo celular: este evento geralmente ocorre no final da fase G1, mediante transcrição p53-dependente de inibidores de Quinases 
Dependentes de Ciclina (CDKs), principalmente a p21. Durante o intervalo onde o ciclo celular estará inibido, dependendo da "gravidade" do dano no DNA, é possível que o material genético seja reparado pela GADD45 (Growth Arrest and DNA Damage). Caso o reparo seja bem sucedido, a p53 regula negativamente sua própria função. Neste evento, ela ativa a transcrição do gene $m d m 2$, cujo produto inibe a ação da p53, permitindo o retorno do ciclo celular, permitindo a passagem da fase $\mathrm{G} 1$ para a fase $\mathrm{S}$ [19].

Apoptose: Ocorre quando não é possível reparar o dano sofrido pelo DNA, visando que a alteração genética não se propague por outra geração de células. O mecanismo com o qual a p53 induz apoptose é pela a transcrição dos genes bax e IGF-BP3. A bax funciona como antagonista de proteínas inibidoras da apoptose, como a bcl-2, e age formando um canal na membrana da mitocôndria liberando para o citoplasma o citocromo $\mathrm{C}$, que ativa a via das caspases e culmina com a morte celular. Já o IGF-BP3 liga-se ao receptor do IGF (Insuline like Growth Factor) inibindo a resposta celular ao fator de crescimento, outra ação que é atribuída à p53 é a inibição da angiogênese [19, 20].

Em condições normais, a p53 encontra-se em baixos níveis celulares, pois é rapidamente degradada [21], não interferindo, portanto, na progressão do ciclo celular e na sobrevivência da célula [22, 23]. Entretanto, na presença de situações de estresse celular que levam o dano do DNA, como radiação UV ou X [22], o TP53 é rapidamente induzido e as células normais aumentam sua expressão para que o ciclo celular seja bloqueado até que haja o reparo do 
DNA. Por outro lado, células com mutações ou outro tipo de inativação do TP53 não têm o ciclo celular bloqueado e continuam a se dividir [22]. Sua inativação pode decorrer de uma gama de alterações, como deleção cromossômica, mutações tipo missense, entre outras, e suas mutações vêm sendo descritas em vários tipos de câncer, como cólon, cérebro, pulmão, fígado, bexiga e estômago [22, 24, 25].

\subsubsection{Mutação do TP53}

Mutação no gene da p53 é encontrada em mais de 50\% dos tumores humanos. Na figura 3, retirada do Banco de Dados de Mutações do TP53 da IARC, pode-se observar que a mutação do TP53 ocorre em $26,2 \%$ dos tumores de fígado. 


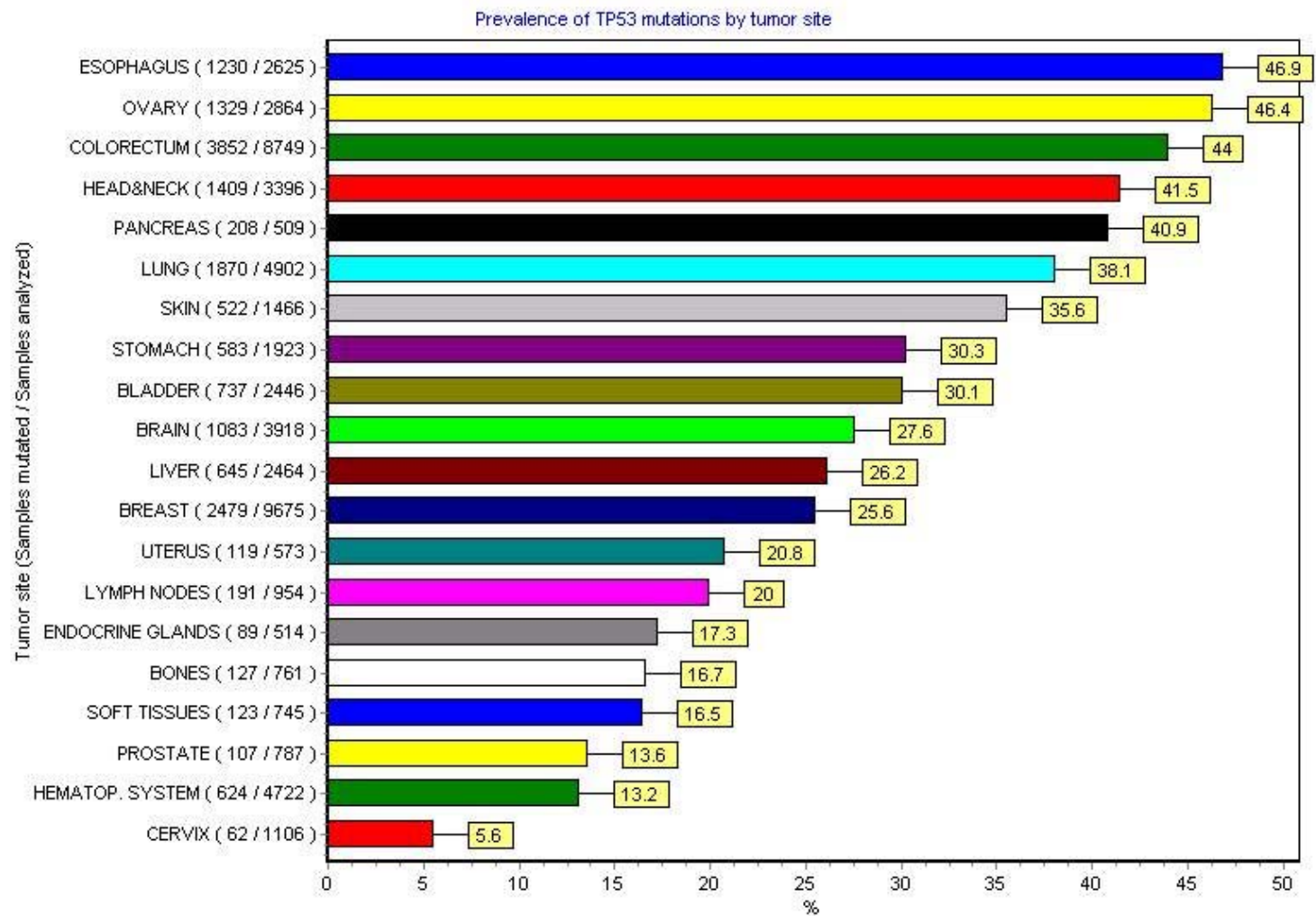

Figura 3: Freqüência de mutação do TP53 em tumores de diferentes órgãos. Fonte: IARC TP53 Mutation Database, Julho de 2004

A distribuição das mutações ao longo dos 11 exons do TP53 não ocorre de maneira randômica, gerando os chamados "Hot-Spots" [26]. As figuras 4a e 4b mostram a distribuição das mutações pontuais ao longo do gene em questão. 
SOMATIC MUTATIONS - Codon distribution of single base substitutions ( $n=16623$ )

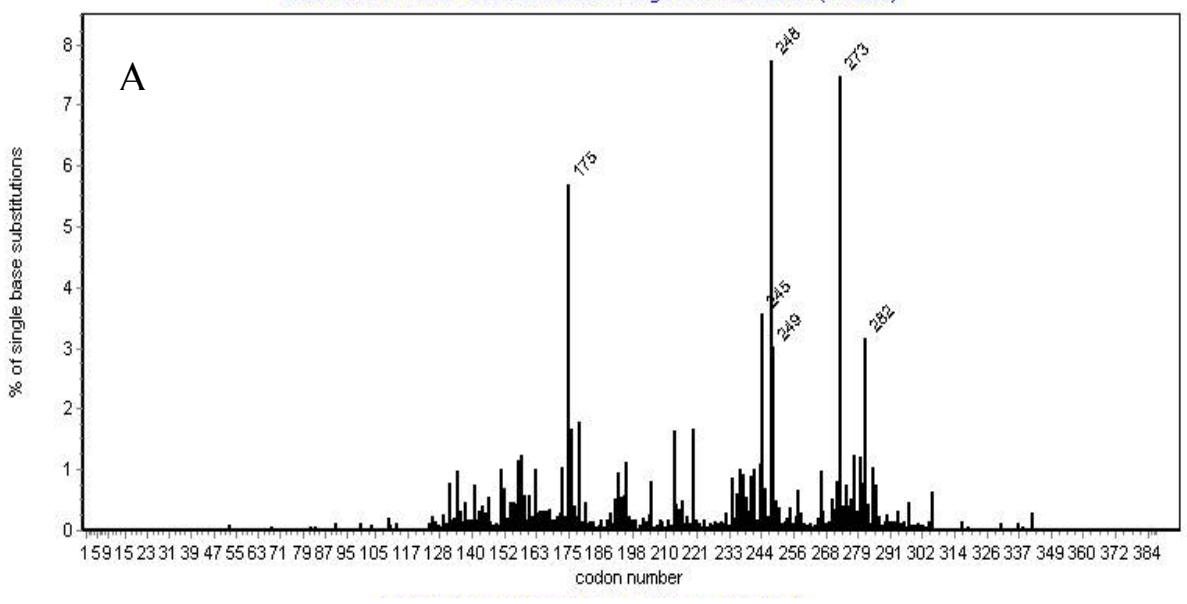

B

CODON DISTRIBUTION / 748 single base substitutions

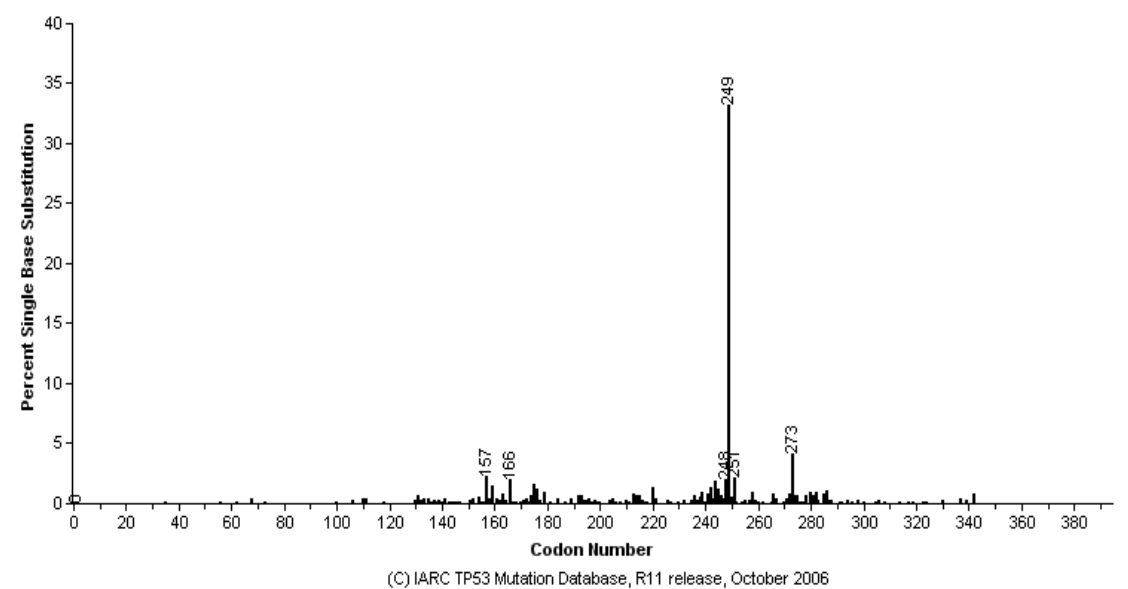

Figura 4: (A) freqüência de Mutações pontuais no TP53 vs Hot-Spot, levando em conta todos os tipos de tumor. (B) freqüência de Mutações pontuais no TP53 vs Hot-Spot apenas no CHC.

Fonte: TP53 database em Dezembro 2006

Tanto a freqüência quanto o tipo e o local da mutação do TP53 no CHC são extremamente variáveis entre diferentes regiões geográficas. Isso se deve principalmente devido a incidência dos vírus das Hepatites $\mathrm{B}$ e $\mathrm{C}$ e contaminação alimentar por aflatoxina. Em regiões de alta incidência do $\mathrm{CHC}$, como China e África, podem-se encontrar alterações na p53 entre $42-52 \%$ dos 
tumores, enquanto em países norte-americanos e europeus esta freqüência é de 0 - 20\%. O Brasil apresenta uma freqüência intermediária de aproximadamente $35 \%$ [24].

Em 1991, dois grupos de pesquisa distintos [5, 6] descreveram uma mutação característica do TP53 induzida pela exposição à alimentos contaminados com aflatoxina presentes na dieta em regiões da China e da África. Ela consiste na substituição de uma guanina (G) por uma timina ( $T$ ) no códon 249 (AGG) no exon 7 e culmina em uma alteração de uma arginina (Arg) para uma serina (Ser), resultando na forma mutante da p53 e, segundo o IARC, este tipo de mutação é a mais freqüente no $\mathrm{CHC}$.

Jackson e colaboradores [27] observaram a presença desta mutação no soro de $46,7 \%$ de pacientes acometidos por $\mathrm{CHC}$ na região de Qidong (China). Em um estudo anterior realizado na Gâmbia [28] além de ser encontrada a mutação no soro de $36 \%$ dos pacientes com CHC também foi possível detectála no soro de $15 \%$ dos pacientes cirróticos, e em $6 \%$ dos pacientes controles.

Em estudo mais recente [29], não foi encontrada $249^{\text {Ser }}$ no plasma de crianças expostas a AFB1 na região de Kindia na Guiné (região endêmica tanto para VHB e AFB1), mesmo que o aducto de aflatoxina-albumina tenha sido encontrado em $96 \%$ das amostras de plasma destas crianças.

A variação geográfica da freqüência da $249^{\text {Ser }}$ pode ser melhor visualizada em uma meta-análise realizada por Stern e colaboradores [30], que apresentou uma revisão sistemática sobre a incidência da mutação (tabela 1) bem como sua associação à infecção pelo VHB. 
Tabela 1: Freqüência da mutação do códon 249 e em outros pontos do TP53 em casos de $\mathrm{CHC}$ em áreas com diferentes níveis de exposição a aflatoxina.

\begin{tabular}{lcc}
\hline Região & Mutação 249 & Outras Mutações no TP53 \\
\hline Alta incidência de AFB1 & & \\
Guangxi, China & $18 / 50$ & $\mathrm{NA}$ \\
Moçambique & $8 / 16$ & $11 / 16$ \\
Qidong, China & $8 / 16$ & $8 / 16$ \\
Qidong, China & $21 / 35$ & $\mathrm{NA}$ \\
Qidong, China & $13 / 25$ & $15 / 25$ \\
Senegal & $10 / 15$ & $\mathrm{NA}$ \\
Africa do Sul & $3 / 10$ & $5 / 10$ \\
Incidência Intermediária & & \\
Durban, Africa do sul & $2 / 24$ & $\mathrm{NA}$ \\
Hong Kong, China & $2 / 26$ & $6 / 26$ \\
México & $3 / 16$ & $\mathrm{NA}$ \\
Shangai, China & $10 / 52$ & $\mathrm{NA}$ \\
Shangai, China & $3 / 10$ & $5 / 10$ \\
Taiwan & $3 / 15$ & $\mathrm{NA}$ \\
Baixa Incidência & & \\
Alasca, EUA & & $0 / 13$ \\
Europa & $0 / 13$ & $1 / 14$ \\
Europa & $0 / 14$ & $6 / 19$ \\
Alemanha & $1 / 19$ & $2 / 13$ \\
Grã-Bretanha & $0 / 13$ & $2 / 19$ \\
Itália & $0 / 19$ & $6 / 20$ \\
Japão & $0 / 20$ & $7 / 43$ \\
Japãp & $0 / 43$ & $10 / 34$ \\
EUA & $3 / 34$ & $\mathrm{NA}$ \\
\hline NA & $4 / 37$ &
\end{tabular}

$\mathrm{NA}=$ não avaliado.

Fonte: Adaptado de Stern et al, 2001

A exposição à Aflatoxina como efeito causal da mutação $249^{\text {Ser }}$ e conseqüentemente o $\mathrm{CHC}$ segue os critérios de Bradford-Hill [31], mostrado na tabela 2. 
Tabela 2: Associação entre AFB1 e $249^{\text {Ser }}$ segundo os critérios de Bradford-Hill

Consistência

\section{Poder da Associação}

- Correlação dose-resposta entre a ingestão estimada de AFB1 e a freqüência da mutação 249Ser em 3 diferentes etnias em 3 diferentes continentes

- 249Ser é encontrada em soro de pacientes expostos a AFB1 e infectados com VHB

- 249Ser é encontrada em CHCs de indivíduos expostos à AFB1 e infectados com VHB mas não apenas infectados com VHB

Especificidade

- 249Ser é incomum em outros tipos de tumores

- 249Ser detectada em soro é um marcador de risco para CHC

Temporalidade

- Células com 249Ser podem ser observadas em fígado não tumoral em áreas de alta incidência de $\mathrm{CHC}$

\section{Evidências Biológicas}

- Estudos laboratoriais demonstram o efeito carcinogênico da AFB1

- A forma metabolicamente ativa da AFB1 liga-se a terceira base $(G)$ do codon 249 do TP53

- Exposição in vitro de células hepáticas à AFB1 induzem a 249Ser

- HBx aumenta a freqüência de 249Ser em células expostas à AFB1

- 249Ser inibe a apoptose e transcrição mediada pela p53, aumentando o crescimento celular

Fonte: Adaptado de Staib et al, 2003

As mutações no códon 249 não são exclusivas do $\mathrm{CHC}$. Hussain e colaboradores observaram que células de pulmão expostas a benzopireno também desenvolvem uma substituição de $\mathrm{G}$ por $\mathrm{T}$, porém na segunda base do códon (AGG - ATG) substituindo uma arginina por uma metionina [32].

\subsection{Aflatoxina}

Aflatoxina é uma micotoxina produzida pelo fungo Aspergillus flavus, endêmico em regiões de clima quente e úmido, geralmente contaminando 
cereais e alimentos secos que ficam armazenados por longos períodos. Por possuir um efeito bioacumulativo, é possível encontrá-la em leite e derivados [33].

Existem mais de 16 tipos de aflatoxinas, mas apenas quatro estão relacionadas a riscos de desenvolvimento de câncer em animais e humanos são elas: B1, B2, G1, G2. As aflatoxinas foram caracterizadas e nomeadas de acordo com a cor da fluorescência que emitem quando iluminadas com luz Ultra Violeta (UV). As aflatoxinas B mostram-se com a cor azul (Blue-azul) e as aflatoxinas G mostram-se com a cor verde (Green-verde), diferenciando-se entre si, B1 - B2 e G1 - G2 pela intensidade da fluorescência [34, 35].

A Aflatoxina B1 (AFB1) possui o maior potencial para causar carcinogênese e é a toxina mais produzida pelos fungos [36, 37, 38].

Em outro grupo está a aflatoxina M1 (AFM1) que é um produto do metabolismo da AFB1. Por ser lipossolúvel a AFM1 pode ser excretada no leite de animais que ingeriram AFB1, podendo posteriormente ser ingerida por humanos [35].

Desde sua descoberta, há mais de 30 anos, muitos estudos debateram a relação entre a AFB1 e o CHC. Entretanto estudos anteriores a 1980 não possuíam condições de avaliar a presença do VHB; da mesma forma que estudos anteriores a 1990 não levavam em conta a possibilidade de infecção por VHC. Desta forma, o papel da aflatoxina na carcinogênese hepática permaneceu obscura até o surgimento das técnicas de biologia molecular e de dosagem de aflatoxinas [39]. 
Para possuir efeito carcinogênico é necessária a conversão da aflatoxina para seu metabólito AFB1-exo-8,9-epóxido. Esta reação também é catalisada pelas enzimas do complexo do Citocromo p450, em especial as isoformas CYP3A4 e CYP1A2 [40]. O epóxido em questão possui a capacidade de ligarse covalentemente com o DNA formando os chamados aductos.

A palavra "aducto" se origina da junção das palavras "adição" e "produto" e se refere a uma entidade química que se forma da união de moléculas mediante à ligações covalentes. Esta ligação é de natureza reversível, portanto os elementos podem eventualmente retornarem a suas formas originais [41].

O principal aducto é resultante da interação do metabólito da AFB1 com guaninas, culminando na formação do complexo AFB1-N7-Gua [36]. Foi demonstrado em estudos in vitro que a AFB1 é capaz de interagir com $20 \%$ das bases entre os exons $5-8$ do gene da p53, 85\% das quais eram Guaninas [42]. Outro grupo relatou a formação de aductos de DNA em outros códons dos exons 7 e 8 deste mesmo gene [43].

Estudos indicam que um fator de risco para formação de aductos é a ineficiência da eliminação dos metabólitos secundários da aflatoxina (em especial o AFB1-exo-8,9-epóxido), realizada por enzimas de fase 2 da biotransformação de xenobióticos (isoformas da família da Glutationa Stransferase), como descrito na figura 5 [44]. 


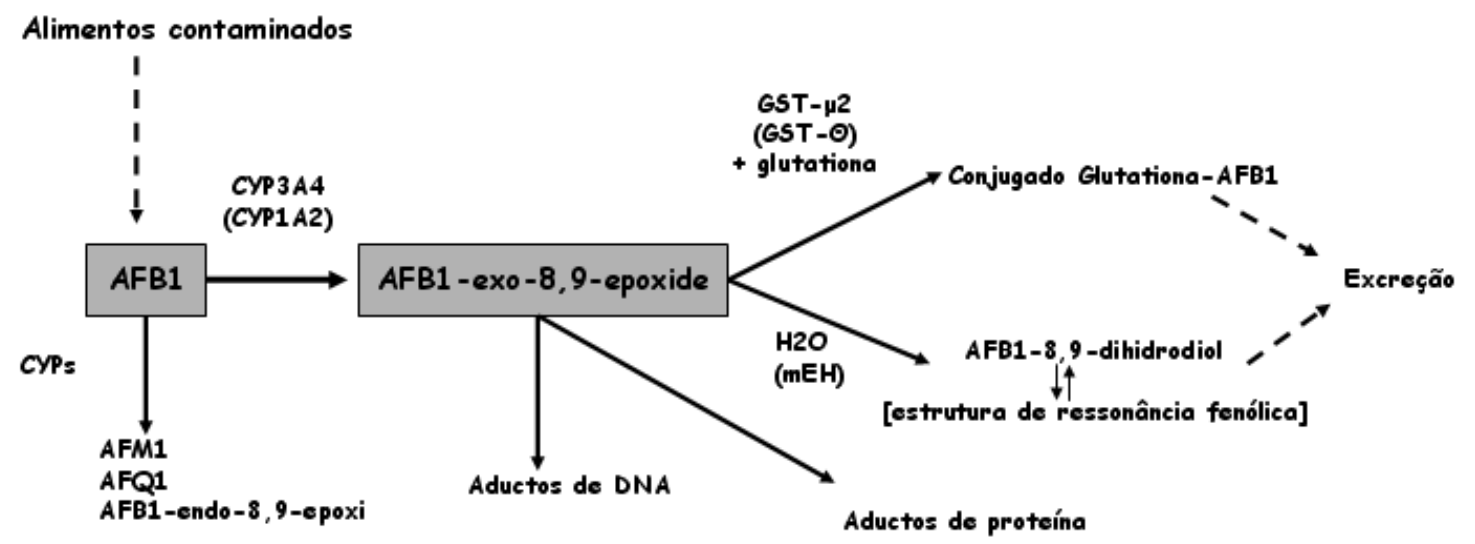

Figura 5: A via metabólica da aflatoxina no organismo

Fonte: Adaptada de Tieremasa et al, 2001

Exposição à AFB1 pode alterar a expressão de alguns genes, incluindo algumas enzimas do CYP450 que estão correlacionadas com a ativação da GST. As variações genéticas populacionais relacionadas às atividades destas enzimas podem explicar as diferenças observadas quanto à ação da toxina.

Já existem medicamentos classificados como quimio-preventivos. O Oltipraz é um membro destas substâncias cuja ação é ativar as enzimas da fase 2 da biotransformação e conseqüentemente acelerar o processo de eliminação do AFB1-exo-8,9-epóxido diminuindo o tempo de permanência do epóxido no organismo e assim o risco de formação de aductos [45].

É importante salientar que existem eventos que podem potencializar o efeito carcinogênico da AFB1. Além da infecção por VHB (que será discutido em seguida) foi descrito que a presença de nematóide Schistosoma pode ter um efeito sinérgico no surgimento da mutação $249^{\text {Ser }}$ [46]. 
A Organização Mundial de Saúde recomenda o controle sistemático dos níveis de aflatoxina nos alimentos, principalmente em paises nas áreas tropicais e subtropicais, onde as condições climáticas são favoráveis à proliferação do Aspergillus flavus.

Desde 1976 no Brasil, a quantidade máxima permitida de Aflatoxina $(A F B 1$ + AFG1) é de 30 ppb ( $\mu \mathrm{g} / \mathrm{kg})$ de acordo com a Resolução - CNNPA n 34, de 1976. Entretanto, em 15 de outubro de 2002, a Resolução RDC n 274 "considerando a importância de compatibilizar a legislação nacional, com base nos instrumentos harmonizados no Mercosul relacionados a limites máximos de aflatoxinas em alimentos" [47], determinou os seguintes limites máximos de aflatoxina:

Tabela 3: Quantidade de Aflatoxina permitida

\begin{tabular}{lcc}
\hline ALIMENTO & AFLATOXINA & LIMITE \\
\hline Leite fluído ou leite em pó & M1 & $0,5 \mu \mathrm{g} / \mathrm{L} 5,0 \mu \mathrm{g} / \mathrm{kg}$ \\
Milho em grão ou farinha & $\mathrm{B} 1+\mathrm{B} 2+\mathrm{G} 1+\mathrm{G} 2$ & $20,0 \mu \mathrm{g} / \mathrm{kg}$ \\
Amendoim ou derivados & $\mathrm{B} 1+\mathrm{B} 2+\mathrm{GI}+\mathrm{G} 2$ & $20,0 \mu \mathrm{g} / \mathrm{kg}$ \\
\hline
\end{tabular}

Fonte: ANVISA

Entre o período de fevereiro de 2005 a julho de 2006 a ANVISA interditou 20 marcas de amendoins e derivados por apresentarem níveis de aflatoxina acima do permitido [48]. 
Em um estudo realizado por Sabino e colaboradores [49] em amostras de amendoim no estado de São Paulo, foi encontrado aflatoxina em 45,3\% das amostras; além disso, $27 \%$ das amostras possuíam níveis de aflatoxina acima do permitido. A concentração máxima de aflatoxina encontrada em doces de amendoim foi de $536 \mathrm{ppb}$, ou seja, 17,8 vezes mais do que o permitido. A União Européia exige normas bem mais rígidas quanto a presença de aflatoxina B1 em alimentos, permitindo apenas $0,1 \mathrm{ppb}$ em alimentos derivados de cereais, possuindo normas específicas para alimentos destinados às crianças (Regulation (EC) 683/2004).

\subsection{Infecção por VHB}

O processo carcinogênico relacionado à infecção por VHB está intimamente ligado à expressão da proteína HBx. Esta oncoproteína demonstrou induzir câncer no fígado de ratos transgênicos [50] e é expressa em mais da metade dos CHCs causados por VHB [51].

Apesar de ainda não existir uma correlação bem estabelecida, vários autores tentaram associar a presença da infecção por VHB com alterações da função do p53. Hosono e colaboradores em 1993 não acharam associação entre estes dois eventos [52]. Mais recentemente constatou-se que a transfecção de VHB altera a expressão do p53 em cultura de células [53]. Estudos em pacientes expostos à aflatoxina e infectados com VHB sugerem uma interação toxina-vírus, onde o VHB estaria relacionado com a seletividade à mutação no códon 249 [54]. 
Foi observado que a HBx tem capacidade de inibir a reparação de nucleotídeos durante a replicação celular, quer seja por ligação à proteínas ligadas à reparação, quer seja pelo dano ao DNA causada pela própria proteína. Isso possibilita que os aductos persistam preferencialmente em pacientes expostos, além da toxina, ao VHB. Além disso, infecção por VHB pode alterar a regulação dos genes do complexo CYP e GST, dificultando a detoxificação da AFB1.

Em um estudo utilizando soro de pacientes de Gâmbia, Kirk e colaboradores [55] detectaram $249^{\mathrm{Ser}}$ em $3,5 \%$ dos pacientes controles, $15,3 \%$ dos cirróticos e $39,8 \%$ dos pacientes com $\mathrm{CHC}$. Os dados sugeriram que a infecção por VHB teria um efeito multiplicativo na incidência da mutação.

\subsection{Patologia do $\mathrm{CHC}$}

$\mathrm{O} \mathrm{CHC}$ é um dos tumores morfologicamente mais heterogêneos, mas geralmente pode-se identificar uma arquitetura formada por trabéculas delimitadas por espaços semelhantes a sinusóides hepáticos. A maioria dos casos de $\mathrm{CHC}$ tem padrão trabecular, podendo ser facilmente diagnosticada como uma proliferação neoplásica por formarem trabéculas largas compostas por hepatócitos atípicos. 
A graduação histológica proposta por Edmondson \& Steiner, em 1954, ainda é a mais usada (Figura 6). Nela o $\mathrm{CHC}$ é dividido em:

- Grau 1: Tumores bem diferenciados com trabeculação delicada

- Grau 2: Estrutura trabecular básica mantida, com aparecimento de estruturas acinares ou granulares e eventualmente áreas papilares. Os núcleos apresentam um grau maior de atipia quando comparados ao grau 1

- Grau 3: Aumento da atipia nuclear, com presença de múltiplos nucléolos, áreas com perda do arranjo trabecular e presença de células gigantes.

- Grau 4: Padrão sólido ou medular de crescimento, as células não são coesas, mostrando formas bizarras e a situação mais freqüente é que haja dificuldade em firmar a linhagem hepatocelular da neoplasia. 

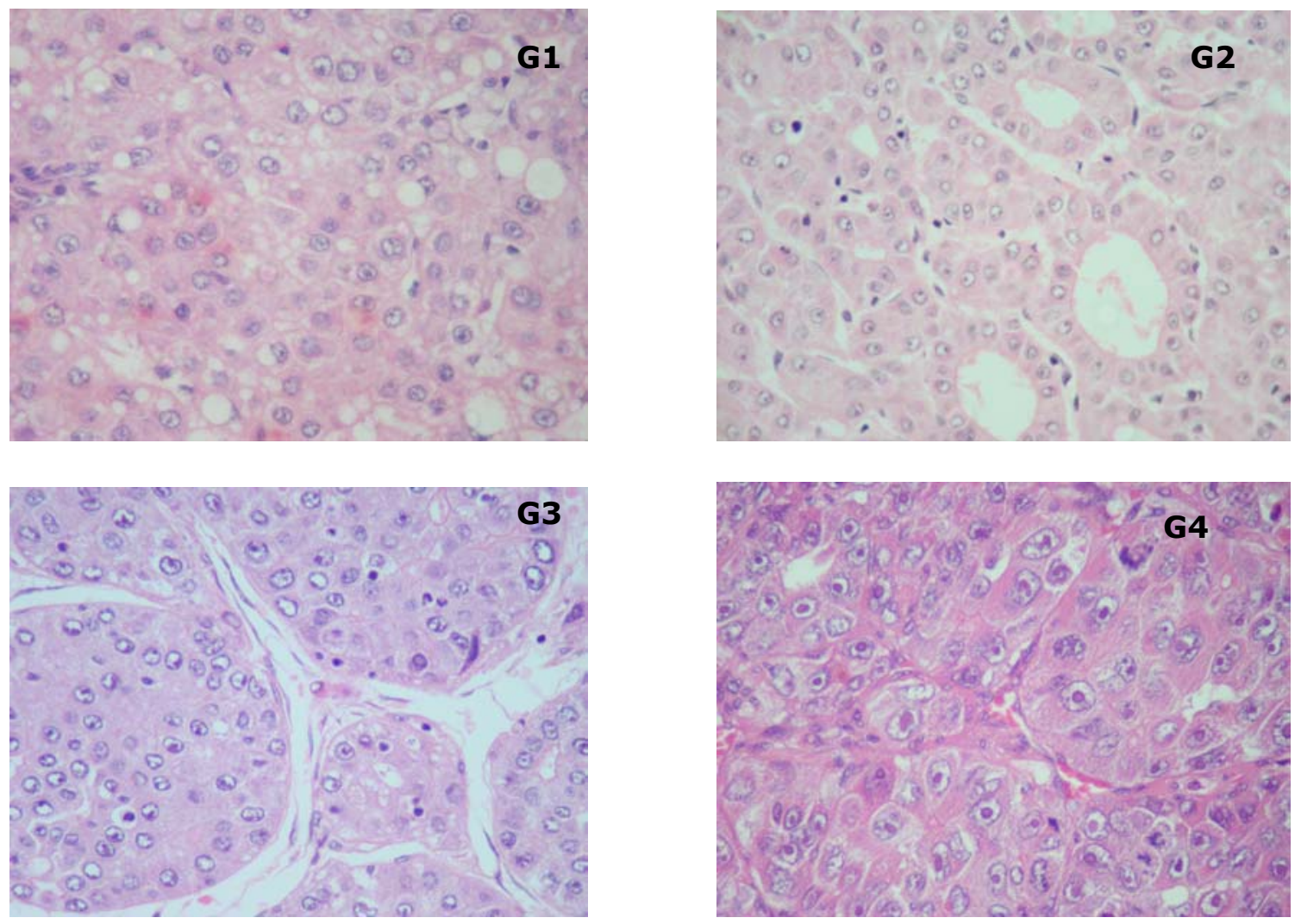

Figura 6: Microscopia óptica de cortes histológicos de $\mathrm{CHC}$ corados com HE, aumento de 400x, representando os diferentes graus do $\mathrm{CHC}$. No sentido horário: grau 1, grau 2, grau 3 e grau 4

\subsection{Prognóstico de CHC}

O prognóstico do paciente com $\mathrm{CHC}$ depende das seguintes variáveis:

1. Estadio do tumor

2. Grau de disfunção hepática no momento do diagnóstico

3. Níveis de Alfa-1-fetoproteína

A classificação mais simples que permite estratificar os pacientes em relação à probabilidade de sobrevida é a proposta por Okuda e colaboradores 
levando em conta o tamanho do tumor, presença de asite, concentração plasmática de bilirrubina e de albumina.

- Estadio 1

- Tumor menor que $50 \%$ do volume hepático

- Ausência de ascite

-Bilirrubina total $\leq 3 \mathrm{mg} / \mathrm{dl}$

- Albumina $\geq 3 \mathrm{mg} / \mathrm{ml}$

- Estadio 2

- Ausência de uma ou duas características do estadio 1

- Estadio 3

- Ausência de três ou quatro das características do estadio 1 [56].

\subsection{Potenciais Impactos do Estudo}

Conforme foi descrito anteriormente, a carcinogênese do $\mathrm{CHC}$ possui diversas vias que podem ser variáveis de acordo com seu fator causal. A aflatoxina mostrou-se como o principal fator causal do $\mathrm{CHC}$ em países africanos e algumas regiões asiáticas, porém esta substância teve papel irrelevante em países europeus e nos EUA [30]. Em países latino-Americanos existem poucos trabalhos avaliando a freqüência da mutação do códon 249 do TP53 no CHC. O único estudo deste tipo realizado foi no México [57] demonstrando que $44 \%$ das amostras de $\mathrm{CHC}$ apresentavam a mutação. Esta freqüência é mais próxima da encontrada em países africanos do que nos EUA. 
Apesar de no Brasil existirem estudos demonstrando a presença de AFB1 acima dos limites aceitáveis [58], nunca houve um estudo em que se avaliou o quanto esta exposição pode estar relacionada à carcinogênese hepática.

Além disso, o conhecimento das alterações genéticas relacionadas ao surgimento do CHC poderá eventualmente ser usado no diagnóstico da doença. Vários trabalhos descrevem a presença da mutação em pacientes acometidos pelo $\mathrm{CHC}$ [59], inclusive alguns estudos citam a presença da mutação em pacientes cirróticos e/ou portadores de VHB [55]; sendo inclusive discutido o uso da análise desta mutação como uma ferramenta diagnóstica para o $\mathrm{CHC}$ [60]. 
2 OBJETIVO 
O objetivo deste estudo é analisar a freqüência da mutação no códon 249 do gene do p53 em amostras de $\mathrm{CHC}$ de pacientes no Brasil, bem como correlacionar esse evento com a presença do DNA do VHB nos hepatócitos e dados anátomo-patológicos. 
3 MATERIAIS E MÉTODOS 


\subsection{Seleção dos pacientes e das amostras a serem estudadas}

Pacientes com diagnóstico de carcinoma hepatocelular confirmada com laudo anátomo-patológico e disponibilizadas nos arquivos do Serviço de Arquivo Médico (SAME) do HC FMUSP. Ainda, os casos foram identificados através do banco de dados do Departamento de Anatomia Patológica do HCFMUSP e no Centro de Imunohistoquímica, Citologia e Anatomia Patológica (CICAP) do Hospital Alemão Oswaldo Cruz. A seleção de pacientes foi limitada entre os anos de 1998 - 2005 no sentido de utilizar peças com menos de 10 anos de preservação em parafina e que tenham sido submetidos a processos de formalização mais adequados para uso em biologia molecular. A constatação da presença do $\mathrm{CHC}$ que contavam nos laudos das amostras foi feita por diagnóstico anatomo-patológicos.

Foram solicitados laudos de pacientes submetidos a transplante ou ressecção hepática devido a $\mathrm{CHC}$ no Departamento de Anatomia Patológica (DAP) e no Centro de Imunohistoquímica, Citopatologia e Anatomia Patológica (CICAP) do Hospital Alemão Oswaldo Cruz. Foram obtidos 208 laudos no DAP e 141 no CICAP. A figura 7 descreve o processo de seleção de casos analisados neste estudo. 


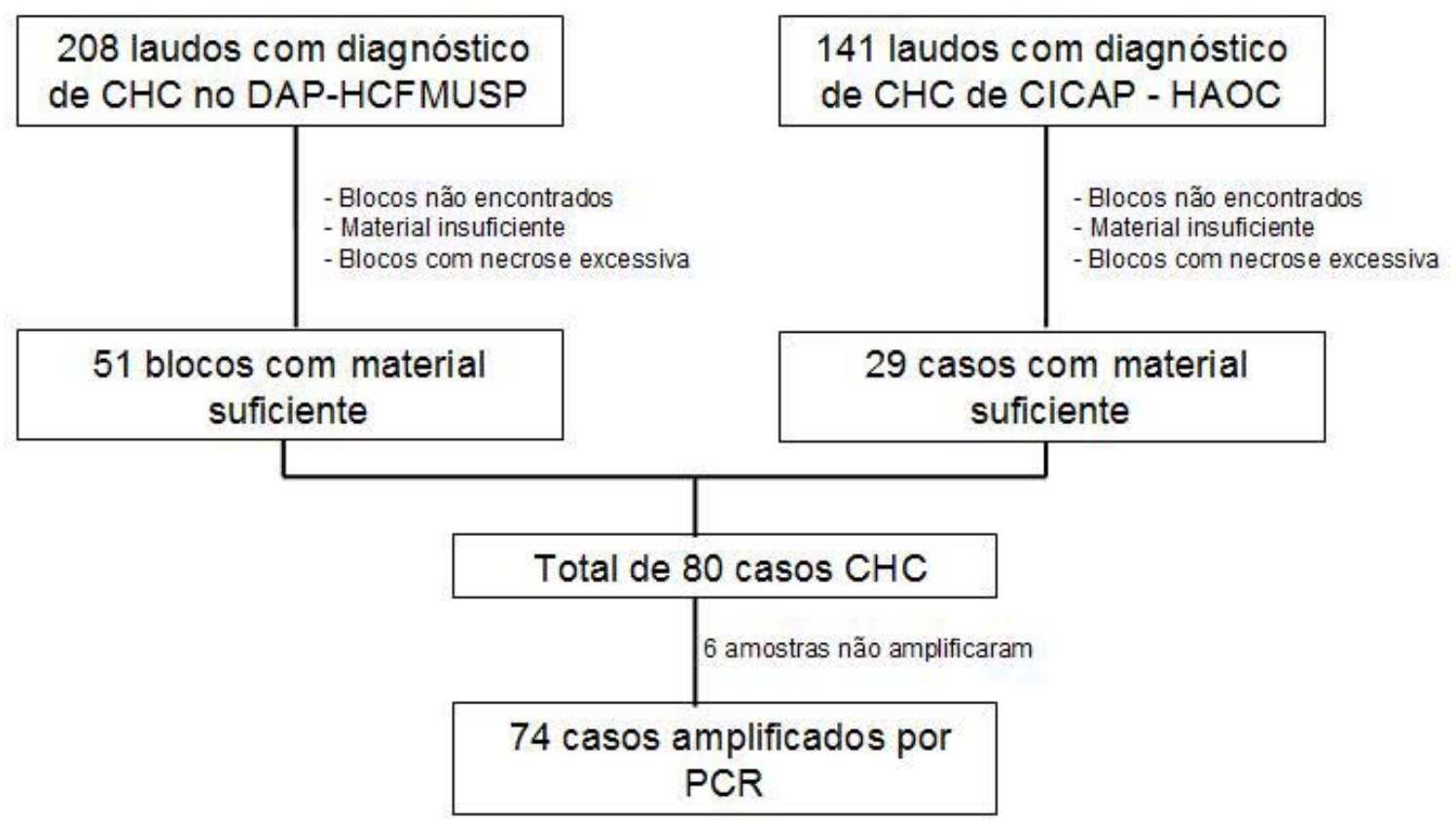

Figura 7: Fluxograma da seleção dos casos.

Casos: Conforme mostra a figura 7 , foram identificados $208+141$ casos com diagnóstico de $\mathrm{CHC}$. Destes foram utilizados 80 peças parafinadas de $\mathrm{CHC}, 51$ delas do departamento de Anatomia Patológica do HC-FMUSP e 29 amostras do Centro de Imunohistoquímica, Citopatologia e Anatomia Patológica (CICAP) do Hospital Alemão Oswaldo Cruz.

Controles: Como grupo controle utilizou-se amostras de fígado que representem uma população não acometida por hepatopatias. Para tanto, foram obtidas peças de fígado não tumoral obtidos no SVO (Serviço de Verificação de Óbito). Essas amostras foram analisadas por patologistas e elas não 
apresentavam nenhum tipo de hepatopatia. Os indivíduos deste grupo faleceram por razões outras que não complicações hepáticas.

Com o objetivo de manter a confidencialidade das amostras e para facilitar o manuseio das mesmas e dos dados, todos os casos foram codificados. Para os casos a codificação foi feita com a sigla HCC seguido pelo numero da amostra. O número de cada amostra seguiu em ordem crescente, de acordo com o seu número do laudo anátomo-patológico. Desta forma a casuística deste estudo foi codificada como HCC001 a HCC080. Os controles foram codificados da mesma forma, utilizando a sigla SVO, seguido pelo número da amostras. Os controles compreenderam as amostras SVO1 SVO17.

As lâminas HE referentes às amostras forma revistas por um patologista participante do projeto a fim de confirmar o diagnóstico que constava no laudo. Neste momento, o patologista também delimitou na lâmina de HE a região representada pelas células tumorais para posterior dissecção desta área.

\subsection{Corte e dissecção das amostras}

As amostras emblocadas obtidas no DAP - HCFMUSP foram cortadas em fragmentos de $10 \mu \mathrm{m}$ por um técnico especializado no uso do micrótomo. Nesta etapa foi utilizando micrótomo e navalhas próprias (Leica, Alemanha) estéreis. Cada navalha foi utilizada apenas para uma amostra, evitando assim contaminação. Os cortes das amostras foram estendidos em laminas foscas de 
vidro para microscópio. O patologista então posicionou as lâminas onde os cortes estavam estendidos ao lado da lâmina HE referente a amostra, cuja a área referente ao tumor já estava delimitada. As amostras foram então macrodissecadas, utilizando bisturis estéreis a fim de reduzir a área com parênquima peri-tumoral, obtendo assim, uma maior porcentagem de material tumoral por amostra.

O material resultante desta macrodissecção foi armazenado em tubos de $1,5 \mathrm{ml}$ (Ependorf $\left.{ }^{\circledR}\right)$ e mantidos ao abrigo da luz e calor até o momento da extração de DNA.

\subsection{Extração de DNA}

As amostras foram desparafinadas mediante ao uso de xilol e etanol. $\mathrm{O}$ DNA foi extraído pelo Qiagen Tissue Mini-kit (Qiagen, Hilden, Alemanha) método baseado na fixação do DNA em coluna de sílica - e posteriormente eluído em um volume de $150 \mu$ de tampão de eluição (constituído de TrisEDTA). A integridade e a quantidade de DNA por amostra foram analisadas por eletroforese em gel de agarose 1,5\% em TAE. O DNA extraído foi armazenado a $-20^{\circ} \mathrm{C}$ até o momento do PCR. 


\subsection{Análise da presença da mutação}

PCR: A região onde se encontra o codon 249 foi amplificada pela Reação em Cadeia da Polimerase (PCR) mediante a utilização de primers específicos.

- Primer Senso: 5'- CTT GCC AC GGT CTC CCC AA - 3'

- Primer Anti-senso: 5' - AG GGT CAG CGG CAA GCA GA - 3'

A seqüência completa do TP53 encontra-se no GeneBank (National Center of Biothecnology Information, http://www.ncbi.nlm.nih.gov) sob o código AY838896. O exon 7 compreende o fragmento entre os nucleotídeos de número 15290 - 15399 desta seqüência. Os primers escolhidos delimitam a região referente aos nucleotídeos numero 15231 - 15468, resultando em um fragmento de $237 \mathrm{pb}$ que possui em sua seqüência todo o exon 7 .

Utilizou-se para cada reação $2 \mathrm{U}$ de Platinum TaqPolimerase (Invitrogen, Carlsbad, USA), primers senso e anti-senso numa concentração final de $0,1 \mu \mathrm{M}$, dNTP a $100 \mu \mathrm{M}, \mathrm{MgCl}_{2}$ a 1,5mM, tampão 1x e água MilliQ autoclavada para completar o volume para $50 \mu \mathrm{l}$. A quantidade de DNA extraído utilizado na reação foi de $5 \mu \mathrm{l}$ (média de 100ng).

Para a ciclagem foi utilizado o Termociclador Mastercycler (Eppendorff), com os seguintes padrões de ciclagem: 
$95^{\circ} \mathrm{C}-5^{\prime}$ (Hot-start da enzima)

$\left.\begin{array}{l}95^{\circ} \mathrm{C}-30^{\prime \prime} \\ 60^{\circ} \mathrm{C}-45^{\prime \prime} \\ 72^{\circ} \mathrm{C}-45^{\prime \prime}\end{array}\right\} 35 \mathrm{x}$

$72^{\circ} \mathrm{C}-10^{\prime}$

Restrição enzimática: Os produtos de amplificação foram analisados por RFLP (Restriction Fragment Leinght Polimorfism) utilizando enzima Hae III (Invitrogen, Carlsbad, EUA). A reação de restrição foi realizada segundo as especificações do fabricante. Esta enzima reconhece a região GGCC, desta forma quando houver mutação (isto é: uma substituição AGG - AGT) a enzima não ira reconhecer o sítio de restrição e o fragmento não será clivado. 0 método de análise da mutação $249^{\text {Ser }}$ em CHC por RFLP foi descrito inicialmente por Aguilar et al, 1993.

O fragmento resultante da PCR possui $235 \mathrm{pb}$ e nele estão contidos 4 sítios de restrição da enzima HaellI. A reação de restrição está esquematizada na figura 8. 
Sítio de restrição Hae III:

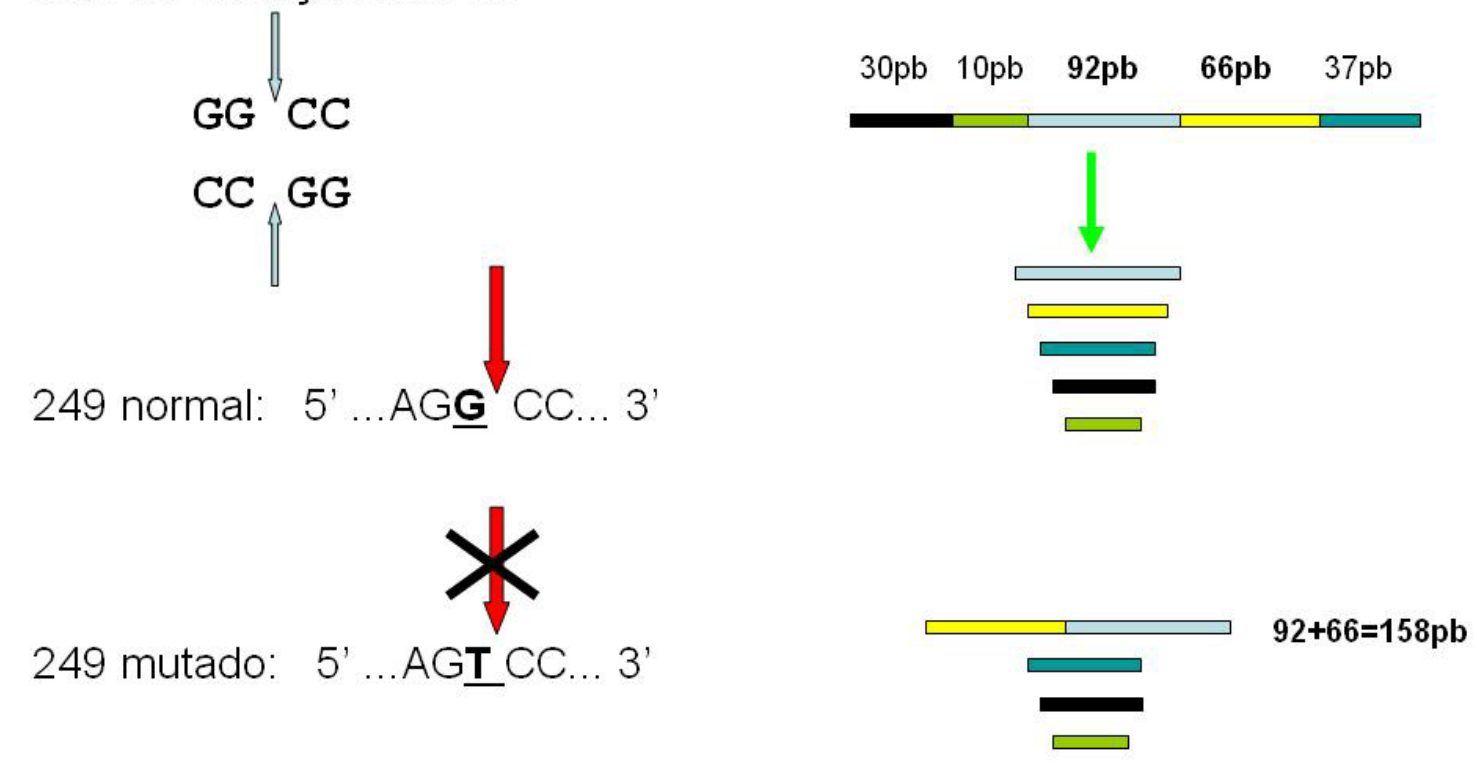

Figura 8: Esquema demonstrando a restrição do fragmento de PCR referente ao exon 7 do TP53. O fragmento possui 4 sítios de restrição para Haelll. Amostras com codon 249 normal irão formar 5 fragmentos de 92, 66, 37, 30 e $10 \mathrm{pb}$ enquanto amostras mutadas se clivarão em 158, 37, 30 e 10pb.

Para a reação de restrição partiu-se de $100 \mathrm{ng}$ de produto de amplificação utilizando $1 \mathrm{U}$ de enzima (um excesso de 10 vezes) junto com o tampão recomendado pelo fabricante. A reação era então encubada a $37^{\circ} \mathrm{C}$ por um período entre $3-6$ horas.

Ao término do período de encubação foi adicionado corante contendo azul de bromofenol (que inibe a atividade da enzima de restrição) na proporção de 1:10 em volume. Após esta adição o produto final foi armazenado a $-20{ }^{\circ} \mathrm{C}$ ou aplicado em gel de agarose imediatamente. 
Os produtos foram aplicados em gel de Agarose 1000 (Invitrogen, Carlsbad, Califórnia) 3\% em TBE (Tris-Borato-EDTA) e submetidos a uma tensão elétrica de 75 volts. Ao término da corrida o gel foi corado em uma solução de brometo de etídeo e visualizado contra uma fonte de luz ultravioleta.

Os produtos gerados na reação de PCR possuem 4 sítios da enzima Hae III, desta forma, uma amostra que não apresenta mutação será clivada em 5 fragmentos: 92 pb, 66 pb, 37 pb, 30 pb e 10 pb. A mutação em questão ocorre no sítio que delimita o fragmento de $92 \mathrm{pb}$ e $66 \mathrm{pb}$; assim sendo um indivíduo que apresenta a mutação possuirá um fragmento de 158 pb.

Sequenciamento: Para a reação de seqüenciamento partiu-se de aproximadamente 40 ng de produto de PCR, primer numa concentração final de 0,32 $\mu \mathrm{M}, 4 \mu \mathrm{l}$ de BigDye Terminator (Applied Biosystems, Foster City, EUA), tampão 1 x e água MilliQ para completar o volume para $20 \mu \mathrm{l}$.

As condições de ciclagem para a reação de seqüenciamento são:

1. $95^{\circ} \mathrm{C}-2^{\prime}$

2. $96^{\circ} \mathrm{C}-10^{\prime \prime}$ $\mathrm{R}=1,0^{\circ} \mathrm{C} / \mathrm{s}$ 3. $50^{\circ} \mathrm{C}-10^{\prime \prime}$ $35 x$

4. $60^{\circ} \mathrm{C}-2^{\prime}$ Hold $10^{\circ} \mathrm{C}$ 
Após precipitação por Isopropanol, a reação de seqüenciamento foi ressuspendida em $3 \mu \mathrm{l}$ de tampão contendo formamida. As reações foram aplicadas em gel de poliacrilamida no seqüenciador automático ABI Prism 377 (AppliedBiosystems, Foster City, EUA). No aparelho as amostras foram submetidas a uma tensão elétrica e migrararam por eletroforese para o pólo positivo onde uma fonte laser fez a leitura dos nucleotídeos. Os dados gerados foram convertidos em cromatogramas e armazenados no computador acoplado ao seqüenciador $\left(\right.$ Macintosh $^{\circledR}$ ). As seqüências obtidas foram transferidas para um computador PC e analisadas utilizando o programa freeware Chromas ${ }^{\circledR}$ (Copyright @ 2003-2007 Technelysium Pty Ltd). 


\subsection{Detecção do DNA do VHB nas amostras}

O mesmo DNA extraído dos fragmentos dos blocos de parafina foi submetido a um ensaio de PCR em Tempo Real a fim de avaliar qualitativamente a presença de DNA do VHB nos hepatócitos.

Para este ensaio utilizou-se primers e sondas da região da proteína $S$ do vírus; estes oligonucleotídeos são específicos para os genótipos $A, B, C, D, E$, F (primers e sondas ainda não publicados).

Para a reação, foi utilizado $5 \mu \mathrm{l}$ de DNA, primers senso e anti-senso a 0,1 $\mu \mathrm{M}$, sonda MGB (Minor Groove Binder) 5'FAM a $50 \mu \mathrm{M}$, 1x TaqMan Mastermix (Applied Biosystems, Foster City, EUA), água MilliQ para um volume final de $25 \mu \mathrm{l}$.

A reação foi feita no termociclador em tempo real SDS 7300 (AppliedBiosystems, Foster City, EUA), com os seguintes parâmetros de ciclagem:

$$
\left.\begin{array}{l}
50^{\circ} \mathrm{C}-2^{\prime} \\
95^{\circ} \mathrm{C}-10^{\prime} \\
95^{\circ} \mathrm{C}-15^{\prime \prime} \\
60^{\circ} \mathrm{C}-1^{\prime}
\end{array}\right\} 40 \mathrm{x}
$$

\subsection{Obtenção de dados clínicos anátomo-patológicos}

O sexo, idade, etiologia, estadiamento do tumor e presença ou ausência de cirrose foram extraídos dos laudos anatomo-patológico obtidos no DAP e 
dos prontuários dos pacientes, obtidos no SAME (Serviço de Arquivo Médico e Estatístico). Também foi utilizado o sistema informatizado do HC para obtenção de dados de sorologia.

\subsection{Análise estatística}

Foi utilizado o teste do Qui-quadrado ou Fisher para comparar proporções. Para as variáveis contínuas (como idade e tamanho de tumor) foi utilizado o teste $t$-student. Odds ratios e intervalos de $95 \%$ de confiança foram calculados para estimar o risco de fatores como VHB e cirrose hepática estarem relacionados ao surgimento da mutação $249^{\text {Ser }}$. Foi empregada a regressão logística multivariada para controlar potenciais fatores de confusão e avaliar possíveis interações. Previamente a esta foi empregado o método univariado com o nível de significância estatística considerada de valor de igual ou menor a 0,2 , visando uma maior flexibilidade na identificação de fatores potencialmente associados com a variável desfecho. A estratégia no método multivariado foi a Stepwise, adotando-se tanto a forward ou backward selection para identificar o melhor modelo. A significância estatística será avaliada pelo teste de razão da verossimilhança. foi considerado estatisticamente significante valor de $p<0,05$.

O programa STATA (Stata Corp, USA) será utilizado para realização dos testes estatísticos. Para testes Chi-quadrado, Fisher e t-student será utilizado o programa Vassar Stats (http://faculty.vassar.edu/lowry/VassarStats.html). 


\section{RESULTADOS}




\subsection{Padronização da Extração de DNA}

Inicialmente optou-se pela realização de um método "in-house" de extração de DNA utilizando xilol e etanol para remoção da parafina, tratamento com proteinase $\mathrm{K}$ para digestão e lise do tecido e Fenol: Clorofórmio: Álcool Isoamílico para a extração de DNA. Entretanto, uma vez que o método possui uma alta porcentagem de perda e material, o resultado obtido não foi satisfatório.

Desta forma optou-se por utilizar um método comercial de extração baseado em coluna de sílica gel. O kit escolhido foi o Qiagen Tissue mini Kit (Quiagen, Hilden, Alemanha), próprio para extração de DNA de amostras de tecido.

A concentração média de DNA obtido por este método foi de $40 \mathrm{ng} / \mu \mathrm{l}$, quantificado por espectrofotometria ou utilizando um padrão de massa (Low Mass Ladder - Invitrogen, Carlsbad, USA).

\subsection{Amplificação por PCR}

Padronização da Reação de PCR: Para testar a qualidade dos primes, as condições de ciclagem e as concentrações dos reagentes, realizou-se um experimento piloto usando como molde DNA extraído de sangue periférico. Cinco microlitros do produto de PCR foram aplicados em gel de agarose $1,5 \%$ em TAE. O marcador utilizado foi o Low Mass Ladder (Invitrogene, Carlsbad, EUA) numa quantidade de $4 \mu \mathrm{l}$. A concentração do produto formado na reação de PCR foi calculada comparando sua intensidade com a intensidade do 
marcador Low Mass, estimando-se uma concentração de $40 \mathrm{ng} / \mu \mathrm{l}$, conforme mostrado na figura 9.

Apesar de possuírem DNA extraído, 6 das 80 amostras não apresentaram amplificação na reação de PCR, desta forma as mesmas foram excluídas do trabalho.

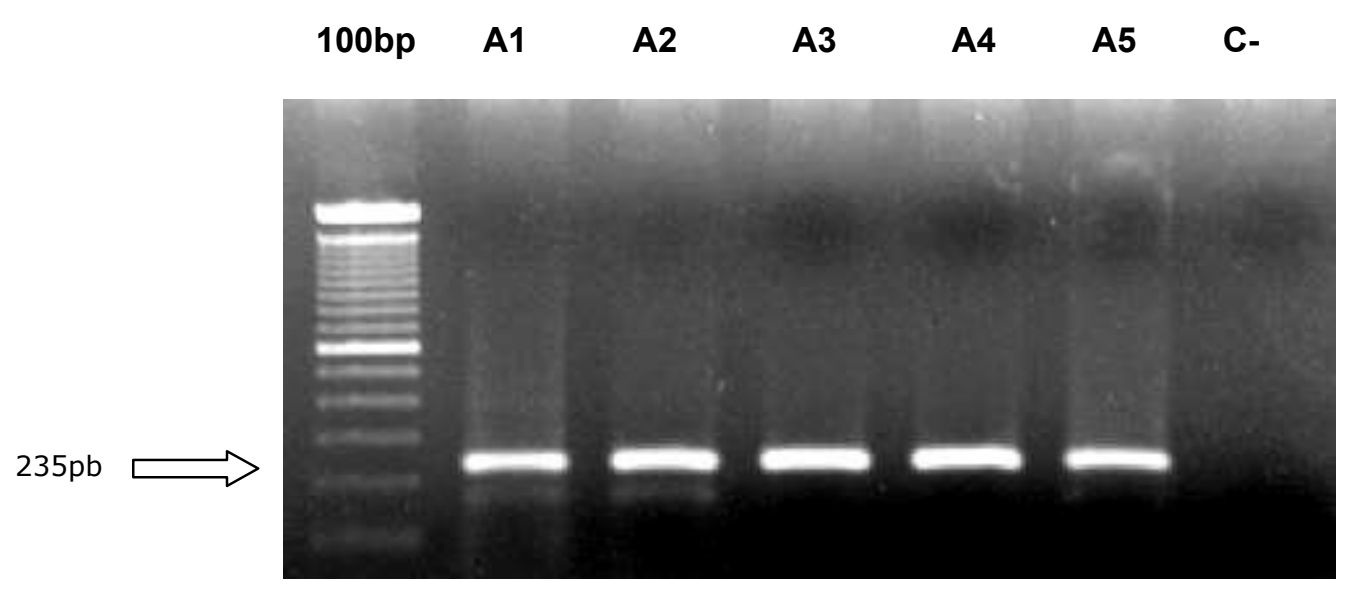

Figura 9: Corrida em gel de agarose 1,5\% TAE de produtos de PCR para o exon 7 do TP53

A eficiência da amplificação em alguns casos foi bastante variável. A

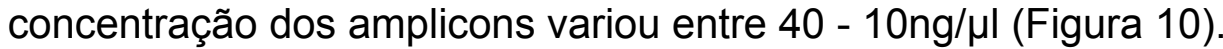

\subsection{RFLP}

A reação de RFLP foi padronizada utilizando produtos de PCR de DNA extraído de sangue periférico e de fragmentos de parafina de fígado saudável. Desta forma não seriam observadas nestas amostras o fragmento de 158pb e a atividade da enzima pode ser testada. 
Uma vez padronizada a reação os produtos de PCR das amostras foram submetidos a esta técnica (Figura 10).

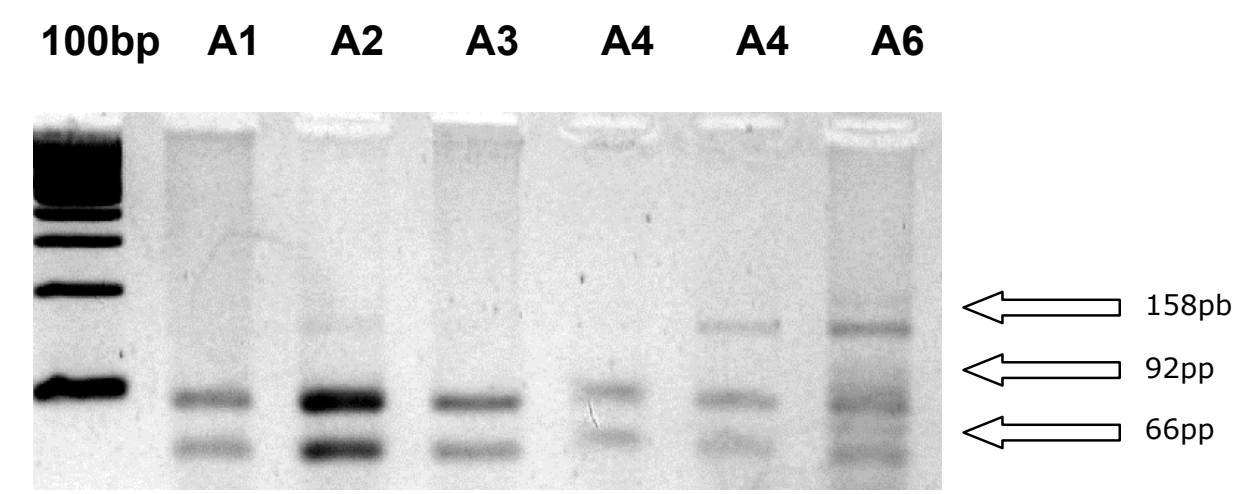

Figura10: Restrição enzimática dos fragmentos de PCR. O fragmento de 158pb indica a presença de mutação do códon 249.

A presença de fragmentos de $92 \mathrm{pb}$ e $66 \mathrm{bp}$ no produto de restrição enzimática indica que havia formas selvagens de p53 junto com a forma mutante. Este fato pode ser causado pela presença de células não tumorais que não foram completamente eliminadas durante a macrodissecção. Outra explicação poderia ser a ocorrência da mutação em heterozigose. A presença destas células, no entanto, não comprometem a detecção da mutação.

A recomendação do fabricante quanto ao uso da enzima para uma digestão completa é a utilização de $1 \mathrm{U}$ de Haell para cada $1 \mu \mathrm{g}$ de DNA e encubar a $37^{\circ} \mathrm{C}$ por 1 hora. Neste estudo foi utilizado $1 \mathrm{U}$ de enzima para cada $100 \mathrm{ng}$ de DNA e a incubação compreendeu um período de $3-6$ horas. Este procedimento visava evitar a ocorrência de digestão incompleta.

Alem disso, o fragmento obtido pela PCR possui 4 sítios de restrição para a enzima Hae III. Desta forma a presença do fragmento de 158 pb só seria devida 
à digestão incompleta caso ele estivesse acompanhado de fragmentos de: 235 pb, 205 pb, 198 pb, 195 pb, 168 pb, 103 pb, 102 pb e 40 pb.

\subsection{Seqüenciamento}

Os produtos de PCR foram purificados e seqüenciados em duplicata. A presença de um pico referente a timina na terceira posição do códon 249 acusava a presença da mutação em questão (Figura 11)
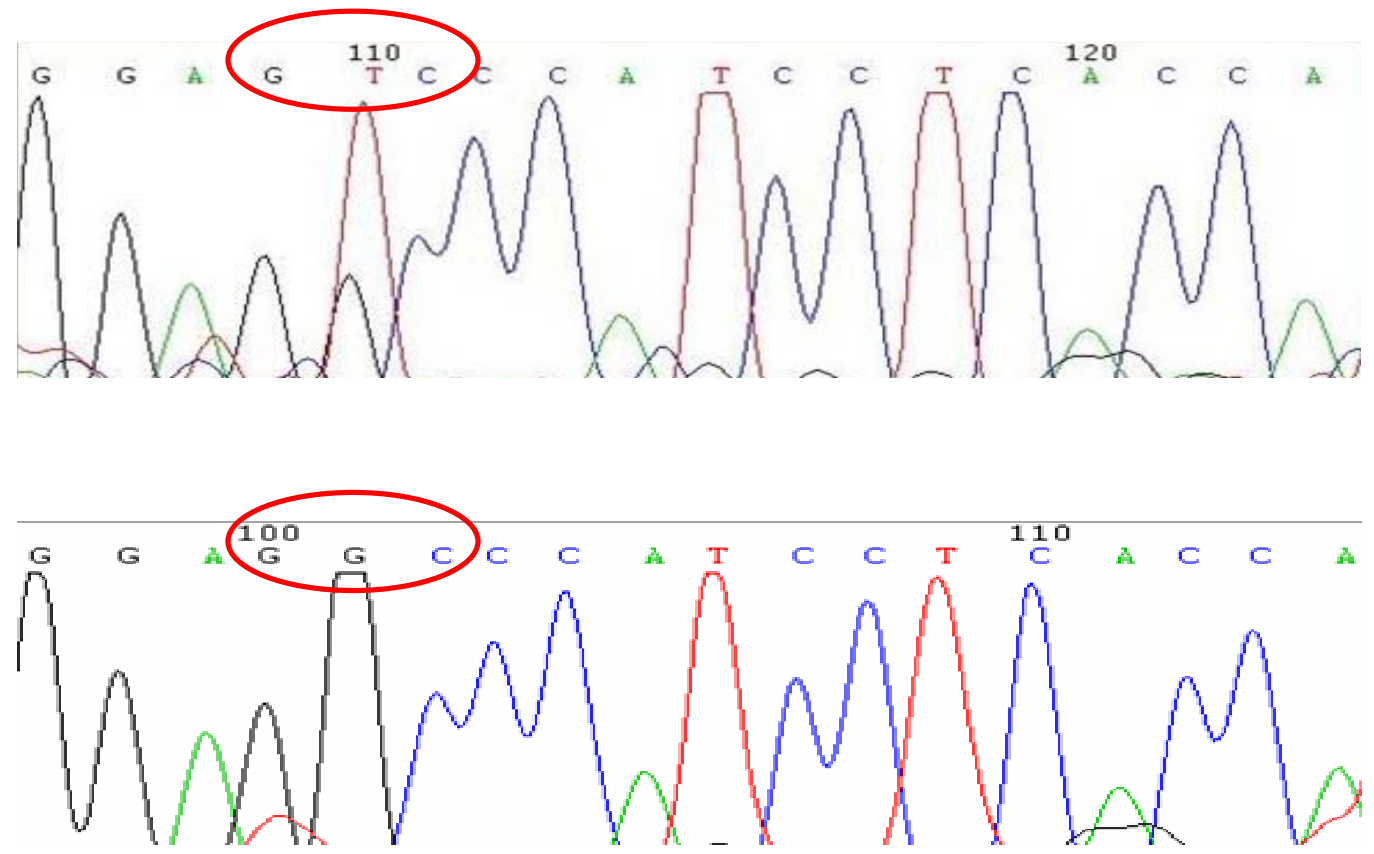

Figura 11: Seqüenciamento do exon 7 do TP53: Circulado em vermelho está o códon 249 , acima está representada uma amostra $249^{\text {Ser }}$, abaixo uma amostra sem mutação neste códon.

Mutação do códon 249 do TP53: A mutação foi encontrada em 21/74 $(28 \%)$ dos pacientes.

Não foi observada a presença da mutação em nenhuma dos 17 blocos de fígado não neoplásico. 


\subsection{Presença de VHB}

Para estabelecer o limite de detecção do ensaio utilizando PCR em tempo real foi realizada uma diluição seriada de uma solução de pSM2 (um plasmídeo que contem todo o genoma do VHB). Esta solução foi diluída seriadamente em razão 10 para observar qual seria a quantidade mínima detectável pelo ensaio. Foi possível observar amplificação de amostras contendo até 5 cópias por reação (Figura 12).

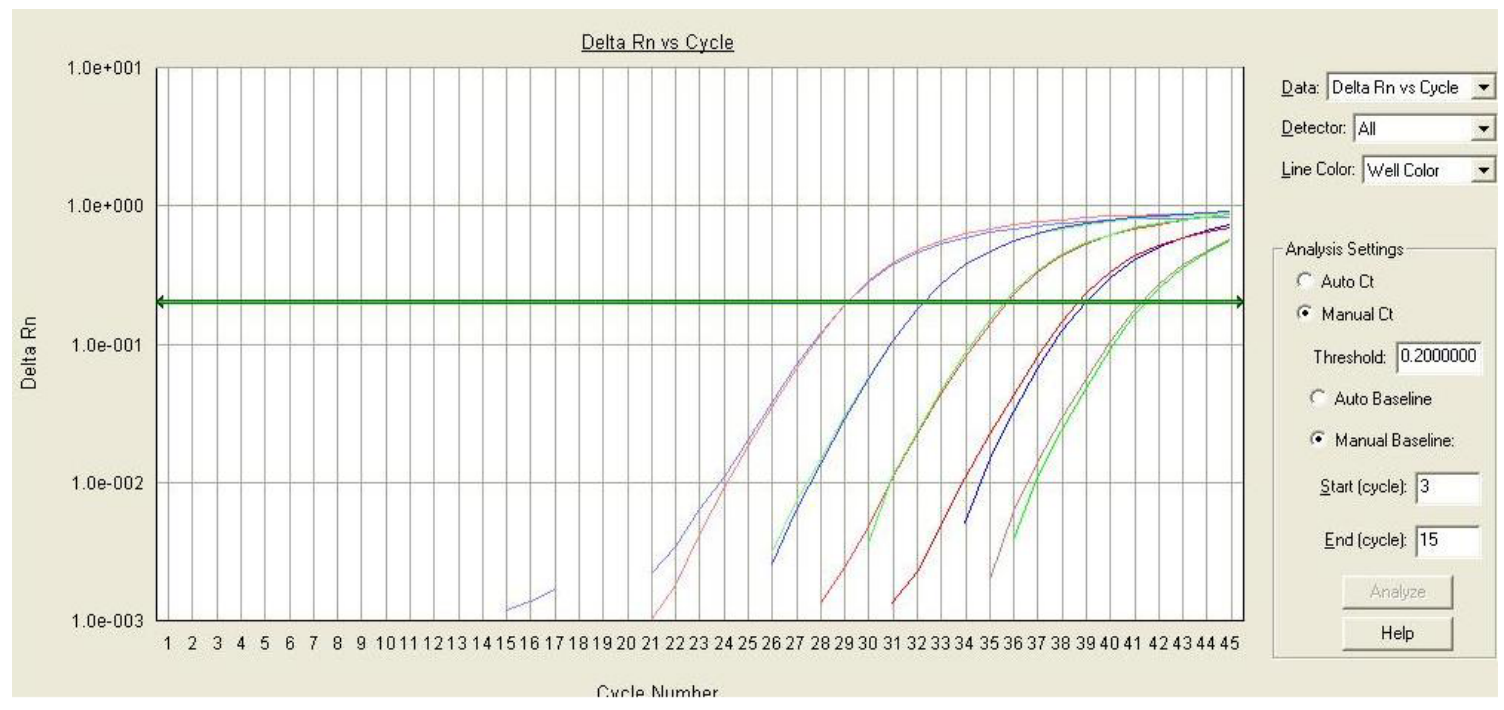

Figura 12: Amplificação por PCR em tempo real da diluição seriada do plasmídeo contendo todo o genoma do VHB. A menor concentração detectável neste método foi de 5 cópias por reação, representando a diluição mais a direita.

O ensaio de PCR em tempo real detectou qualitativamente a presença do DNA do VHB em 12/74 (16,2\%) das amostras (Figura 13). 


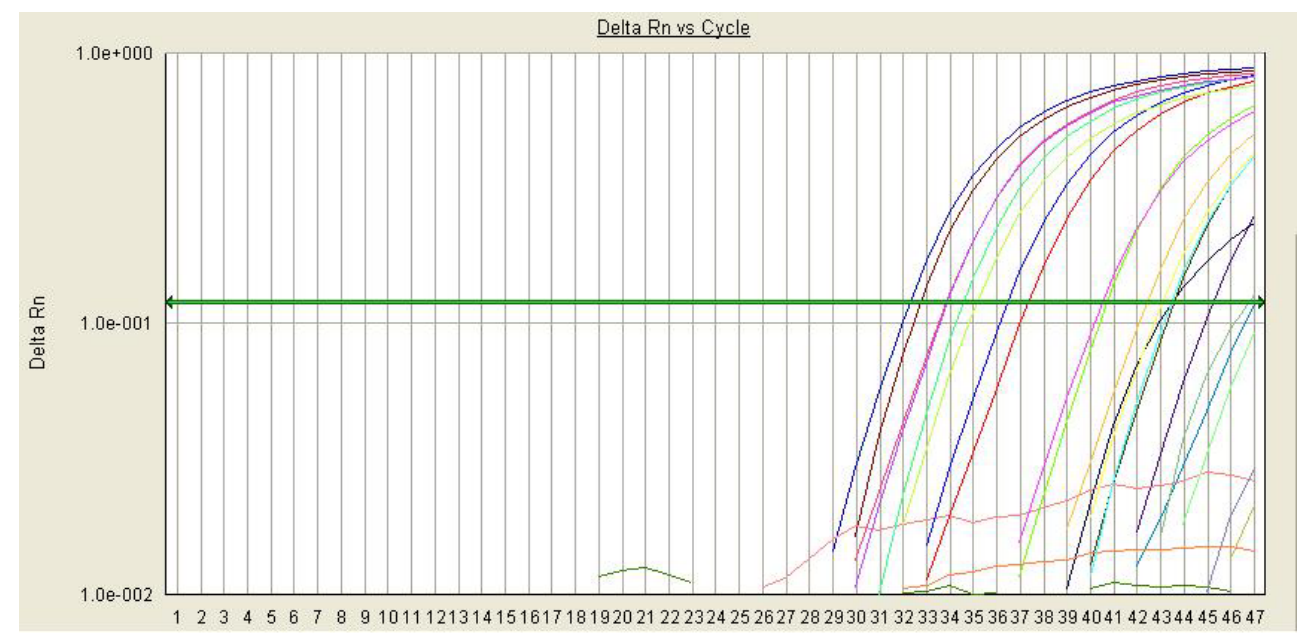

Figura 13: Amplificação por PCR em tempo real do DNA do VHB por PCR em tempo real, determinando a presença do DNA viral nos hepatócitos.

\subsection{Variáveis relacionadas com a presença da mutação $249^{\text {Ser }}$}

A freqüência da mutação de acordo com cada grau de diferenciação tumoral foi: 0/1 (0\%) em G1, 7/30 (23,3\%) em G2, 8/24 (23,5\%) em G3 e 6/9 $(66,7 \%)$ em G4, os dados estão expostos na tabela 3. A maior freqüência da mutação em tumores classificados como menos diferenciados (G4) foi estatisticamente significante maior, aplicando o teste de Pearson $(p=0,054)$ (Tabela 4).

Tabela 4: Análise de Pearson chi2 correlacionando presença da mutação e grau de diferenciação tumoral: Pearson chi2(3) $=7,6567, p=0,054$.

\begin{tabular}{lccccc}
\hline & \multicolumn{5}{c}{ Grau Histológico } \\
& $\mathbf{1}$ & $\mathbf{2}$ & $\mathbf{3}$ & $\mathbf{4}$ & Total \\
\hline Sem Mutação & 1 & 23 & 26 & 3 & 53 \\
Com Mutação & 0 & 7 & 8 & 6 & 21 \\
Total & 1 & 30 & 3 & 9 & 74 \\
\hline
\end{tabular}


Ao comparar a freqüência da mutação em tumores menos diferenciados ( $\mathrm{G} 4=66,7 \%)$ com as demais formas (G1 - G3 = 23\%) a significância estatística fica ainda mais evidente de acordo com o teste Fisher $(p=0,01)$.

VHB DNA foi detectado em 2/11 (18\%) e 11/65 (17\%) dos tumores com grau G4 e em grau G1 - G3 respectivamente.

Dados sobre o tamanho do tumor estavam disponíveis para 68 amostras. O tamanho médio dos tumores que apresentavam a mutação foi de $9,39 \mathrm{~cm}$ enquanto os tumores que apresentavam o códon 249 em sua forma normal tiveram uma média de tamanho de $5,5 \mathrm{~cm}(p=0,015)$, conforme descrito na tabela 5 .

Tabela 5: Associação entre tamanho de tumor e presença da mutação

\begin{tabular}{ccc}
\hline Mutação & $\mathrm{N}^{\circ}$ de Amostras & Tamanho médio $(\mathrm{cm})$ \\
\hline Ausente & $49^{*}$ & 5,5 \\
Presente & $19^{*}$ & 9,39
\end{tabular}

*Apenas 68 laudos possuíam informação sobre o tamanho do tumor $(p=0,015)$

$\mathrm{Na}$ análise multivariada (descrita na tabela 6) foi constatado que o grau mais indiferenciado de $\mathrm{CHC}$ representa um $\mathrm{OR}=2,415$ (IC = 1,0001 - 5,8249; $p=0,050)$; o sexo masculino representou um $\mathrm{OR}=4,917$ (IC $=0,9540-$ $25,3453 ; p=0,057)$ e o tamanho tumoral $O R=1,102(I C=1,0011-1,2145 ; p=$ $0,047)$. 
Tabela 6: Análise multivariada dos fatores que possuem relação com a presença da mutação 249Ser.

\begin{tabular}{cccc}
\hline & Odds Ratio & $95 \%$ Conf. Interval & $\mathrm{P}$ \\
\hline Grau Tumoral & 2,415 & $1,001338-5,82469$ & 0,050 \\
Sexo & 4,917 & $0,9540522-25,3453$ & 0,057 \\
Tamanho do Tumor & 1,102 & $1,00114-1,21455$ & 0,047 \\
\hline
\end{tabular}

Pacientes com tumores menos diferenciados possuem uma média de idade de $43 \pm 21$ anos enquanto pacientes com $\mathrm{CHC}$ de graus $\mathrm{G} 1-\mathrm{G} 3$ possuem $55 \pm 17$ anos $(p>0,05)$.

A idade media de pacientes com $249^{\text {Ser }}$ foi de $53,05 \pm 12,35$ anos contra $54,41 \pm 18,98$ anos em pacientes com a forma não mutada do códon 249 , esta diferença não foi estatisticamente significante $(p=0,3825)$.

A freqüência da mutação foi de $3 / 21(14,28 \%)$ em mulheres e 18/53 $(33,9 \%)$ em homens $(p=0,076)$.

A freqüência de $249^{\text {Ser }}$ em $\mathrm{CHC}$ provenientes de fígado cirrótico foi de $34,7 \%$ e $16 \%$ em tumores de fígado não cirrótico $(p=0,0760)$.

A presença do DNA do VHB não esteve relacionada com a presença ou ausência de cirrose $(p=0,2886)$.

Nem a mutação $249^{\text {Ser }}$ nem a presença do DNA do VHB tiveram relação com a invasão vascular $\mathrm{OR}=0,84(\mathrm{IC}=0,3033-2,3266 ; \mathrm{p}=0.470)$ e $\mathrm{OR}=$ $1.0102(I C=0.3039-3.3577 ; p=0.611)$ respectivamente. 
Foi também observada a presença da mutação $249^{\text {Ser }}$ em um paciente acometido por Esquistossomose hepática. 
5 DISCUSSÃO 
A presença de mutação no codon 249 do TP53 foi encontrada em $28 \%$ dos casos de $\mathrm{CHC}$ estudados. Em um estudo anterior, Alves e colaboradores [24] constataram uma hiperexpressão da p53 em 35\% dos casos de $\mathrm{CHC}$ em pacientes brasileiros. Entretanto a metodologia utilizada para a pesquisa foi a de imunohistoquímica, permitindo apenas averiguar a existência de mutação, e não o "hot-spot" preciso. Uma vez que no CHC o principal "hot-spot" do TP53 é o códon 249 pode-se afirmar que este resultado era esperado. É importante salientar que apesar do codon 249 ser responsável por 33\% das mutações do TP53 no CHC ele não é o único hot-spot do TP53 neste tipo de tumor. Segundo o TP53 database [61] este gene possui 143 hot-spots além do codon 249 descritos no $\mathrm{CHC}$. O segundo hot-spot mais freqüente no $\mathrm{CHC}$ é o codon 273 contribuindo com 4,14\% das mutações do TP53. Este codon é seguido pelos $251(2,14 \%)$ e $248(2 \%)$. Os outros codons contribuem individualmente com menos de $2 \%$ das mutações, entretanto, ao todo suas contribuições somadas chegam a $60 \%$ das mutações do TP53.

Os resultados obtidos neste estudo e no de Alves e colaboradores [24] contrastam com dados publicados por estudos em paises europeus, onde a mutações do TP53 no $\mathrm{CHC}$ é um evento extremamente raro. No estudo realizado por Kubicka na Alemanha [62] nenhuma das 20 amostras de $\mathrm{CHC}$ apresentou mutação do códon 249 do TP53, e entre elas apenas uma demonstrou possuir uma hiperexpressão de p53, avaliada por imunohistoquímica. Seqüenciado esta amostra, foi demonstrado que esta hiperexpressão era causada por uma mutação no códon 248. Da mesma forma, 
um estudo realizado nos EUA [63] demonstrou que apesar de ser observado alterações imunohistoquímicas de p53 em 5/23 (21,74\%) pacientes com CHC, todos os 5 casos eram selvagens para o códon 249. Esta mutação, entretanto já foi descrita em estudos nos EUA, mesmo em baixa freqüência: Goldblum demonstrou em 1993 que 11\% de suas amostras possuíam mutação do códon 249 [64].

Não existem muitos estudos sobre a freqüência da mutação $249^{\mathrm{Ser}}$ em paises latino-americanos. No México foi descrita uma freqüência desta mutação de $44 \%$ [57]. Esta alta freqüência de $249^{\text {Ser }}$ pode estar relacionada com o fato de o México ser um dos maiores consumidores de milho do mundo (120 Kg per capta ao ano). Isso associado a um mau armazenamento e manipulação do milho e seus derivados resultam em uma grande ingestão de aflatoxina por parte da população. Além disso, existem ainda pontos falhos quanto às normas que regulam os níveis de ABF1 neste país. Por exemplo, até 2005 não existiam regras quanto à presença de aflatoxina no leite e seus derivados [65].

Por outro lado, em países com alta incidência de $\mathrm{CHC}$ a mutação do códon 249 desempenha um papel importante. Em Senegal este tipo de mutação chega a ser detectado em $67 \%$ dos pacientes [66]. Em regiões como Gâmbia (África) e Qidong (China) os índices deste tipo de mutação podem chegar a 50\%. A freqüência encontrada para essa mutação específica no presente estudo foi de $28 \%$, muito superior a países europeus, porém abaixo de paises onde a exposição à aflatoxina é endêmica. 
Apesar da contaminação por aflatoxina no Brasil ser combatida pela ANVISA, entre o período de fevereiro de 2005 a julho de 2006, esta interditou 20 marcas de amendoins e derivados por apresentarem níveis de aflatoxina acima do permitido [48] - ainda são publicados estudos que constatam presença da AFB1 acima dos limites tolerados. Outro ponto que precisa ser salientado é que até 2002 o limite de aflatoxina em alimentos era de 30ppb, enquanto em paises com baixa incidência de $\mathrm{CHC}$, como os EUA, o limite é de $15 \mathrm{ppb}$.

Não foi observada correlação estatística entre a presença da mutação do códon 249 e a presença do DNA do VHB nas amostras tumorais. Entretanto, neste ensaio apenas foi analisada a presença do DNA total do vírus, e não sua expressão gênica. Como é descrito em trabalhos anteriores o processo pelo qual o VHB leva ao surgimento da $249^{\text {Ser }}$ estaria relacionado à ação da proteína HBx (que não foi estudada neste projeto).

O fato dos resultados obtidos neste estudo apontarem que a $249^{\text {Ser }}$ está relacionada com tumores maiores e menos diferenciados poderia sugerir que esta mutação é um efeito tardio na carcinogênese hepática. Esta afirmação poderia soar contrária à hipótese de que a AFB1 é um fator causal do $\mathrm{CHC}$ no Brasil. Entretanto, existem estudos relatando as vantagens seletivas que células portadoras destas mutações possuem. Entre elas, podem ser citadas: Aumento do crescimento celular avaliado in vitro após a transfeção de células com $249^{\text {Ser }}$ em células normais [67], inibição da via da apoptose mediada pela forma não 
mutada da p53 [68] e finalmente a forma $249^{\text {ser }}$ da p53 possui maior eficiência que as outras mutações em suprimir a atividade de p53 normal [69].

Oda et al [70] já haviam descrito que mutações no gene TP53 estavam associadas a uma menor diferenciação do $\mathrm{CHC}$. Mais tarde $\mathrm{Ng}[71,72]$ chegou a uma mesma conclusão. Entretanto, em ambos os trabalhos havia uma baixa freqüência da mutação $249^{\text {Ser }}$ e os dados foram relacionados à mutações do TP53 de maneira geral, e não especificamente ao códon 249. Apesar de não ter demonstrado significância estatística, foi observado uma tendência de que a mutação foi mais freqüente em fígado cirrótico em relação ao não cirrótico. Mesma tendência foi demonstrada quanto ao sexo: a mutação foi mais freqüente em homens em relação às mulheres $(p=0,076)$.

A presença da mutação $249^{\text {Ser }}$ em um paciente acometido por esquistossomose hepática sugere que o Schistosoma pode contribuir para a carcinogênese hepática via TP53 e pode ter um fator sinérgico a AFB1 como descrito por Habib [46]. Entretanto em nossa casuística apenas um paciente era portador deste parasita, demandando novos estudos para avaliar a relação Schistosoma/AFB1 no CHC.

Devido à falta de tempo, até o fechamento desta dissertação não foi possível realizar um ensaio imunohistoquímico para avaliar a expressão da p53 nesta casuística. Com os dados de imunohistoquímica seria possível avaliar qual amostra que - apesar de não apresentar mutação no códon 249 - possui hiperexpressão da p53. Essa informação seria útil para direcionar a pesquisa de outros "hot-spots" do TP53 relacionados com o CHC em pacientes no Brasil. 
Como grupo controle neste estudo foram utilizadas amostras de fígado necropsiado de indivíduos sem hepatopatias, para avaliar a presença da mutação no fígado saudável. Entretanto, um grupo interessante para ser utilizado (tendo em vista os dados obtidos) seriam amostras de fígado cirrótico ou com hepatites crônicas. Como a mutação estudada é um fator causal do $\mathrm{CHC}$, ela teoricamente deveria estar presente em algumas amostras que possivelmente evoluirão para o $\mathrm{CHC}$.

Uma vez que as amostras parafinadas obtidas para o presente estudo datam de 1996-2005, foi observado um baixo rendimento referente à concentração de DNA obtida, alem disso o DNA apresentou-se extremamente degradado. Comparando o DNA extraído de parafina com DNA extraído de sangue periférico armazenado a $-20^{\circ} \mathrm{C}$ fica evidente a diferença de integridade e de quantidade. 


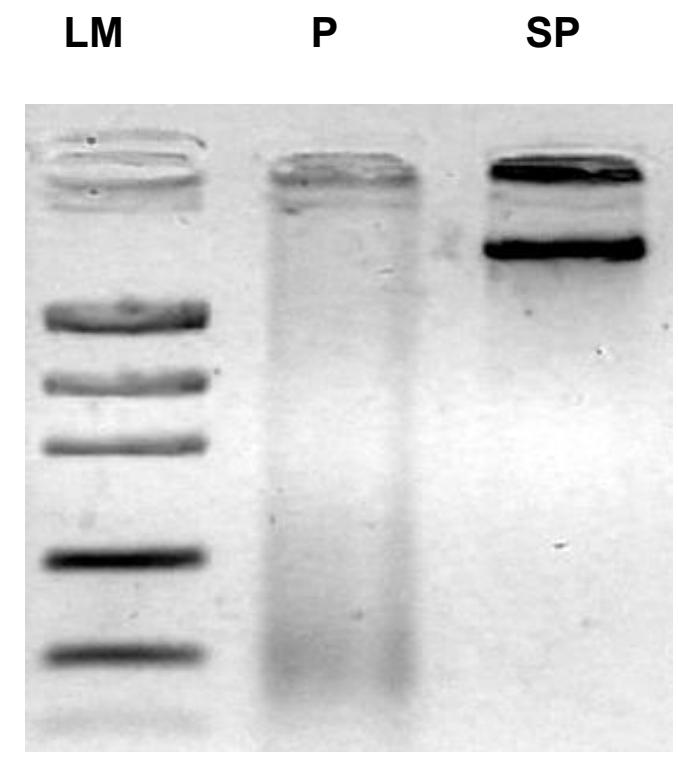

Figura 15: Comparação entre DNA extraído de parafina $(P)$ e de sangue periférico (SP) armazenado a $-20^{\circ} \mathrm{C}$. O marcador de peso molecular e de concentração utilizado foi o Low Mass Ladder (LM)

Isso pode ter sido um dos fatores responsáveis pela baixa eficiência da reação de PCR em algumas amostras, inclusive pela ausência de amplificação de 6 delas.

A degradação excessiva do DNA não é apenas pelo fato da idade da amostra: um dos maiores motivos deste fenômeno é o período em que a peça cirúrgica fica imersa em formol. Após 8 dias em formol tamponado, o DNA de uma peça não produz fragmentos de PCR maiores que 989pb; após 30 dias em formol tamponado, só é possível amplificar fragmentos de até 268pb [73].

No Departamento de Patologia do HC-FMUSP não há um critério rígido de permanência da peça no formol. A amostra fica no mínimo $24 \mathrm{~h}$ em formol podendo ficar até 10 dias. Este fato pode comprometer a integridade do material genético já que uma armazenagem em formol (mesmo que 
tamponado) por um período superior a uma semana é suficiente para a degradação dos ácidos nucléicos [74].

Outro obstáculo enfrentado neste estudo foi em relação à obtenção de dados clínicos dos pacientes. Como a maioria dos pacientes já havia falecido, seus prontuários encontravam-se inativos, além disso, nem todos os prontuários possuíam as informações necessárias. 
6 CONCLUSÃO 
1- Foi possível concluir neste estudo que no Brasil a mutação pontual no códon 249 do TP53 é um fator significante na carcinogênese do CHC estando presente em $28 \%$ das amostras, sugerindo a presença de aflatoxina nos alimentos. Esta freqüência é maior que a encontrada em países com baixa exposição à AFB1, porém menor que em países com alta exposição.

2- Neste estudo a presença de VHB não demonstrou estar relacionada com o surgimento da mutação no códon 249 do TP53.

3- A mutação está associada a uma forma maior e menos diferenciada de $\mathrm{CHC}$. 
[1] Parkin DM. Global cancer statistics in the year 2000. The lancet oncology. 2001 Sep;2(9):533-43.

[2] Nita ME, Alves VA, Carrilho FJ, Ono-Nita SK, Mello ES, Gama-Rodrigues JJ. Molecular aspects of hepatic carcinogenesis. Revista do Instituto de Medicina Tropical de Sao Paulo. 2002 Jan-Feb;44(1):39-48.

[3] Bruix J, Llovet JM. Hepatocellular carcinoma: is surveillance cost effective? Gut. 2001 Feb;48(2):149-50.

[4] Rocken C, Carl-McGrath S. Pathology and pathogenesis of hepatocellular carcinoma. Digestive diseases (Basel, Switzerland). 2001;19(4):269-78.

[5] Hsu IC, Metcalf RA, Sun T, Welsh JA, Wang NJ, Harris CC. Mutational hotspot in the p53 gene in human hepatocellular carcinomas. Nature. $1991 \mathrm{Apr}$ 4;350(6317):427-8.

[6] Bressac B, Kew M, Wands J, Ozturk M. Selective G to T mutations of p53 gene in hepatocellular carcinoma from southern Africa. Nature. 1991 Apr 4;350(6317):429-31.

[7] Bosch FX, Ribes J, Borras J. Epidemiology of primary liver cancer. Seminars in liver disease. 1999;19(3):271-85.

[8] Tagger A, Donato F, Ribero ML, Chiesa R, Portera G, Gelatti U, et al. Case-control study on hepatitis $C$ virus $(\mathrm{HCV})$ as a risk factor for hepatocellular carcinoma: the role of HCV genotypes and the synergism with hepatitis B virus and alcohol. Brescia HCC Study. International journal of cancer. 1999 May $31 ; 81(5): 695-9$.

[9] Monto A, Patel K, Bostrom A, Pianko S, Pockros P, McHutchison JG, et al. Risks of a range of alcohol intake on hepatitis C-related fibrosis. Hepatology (Baltimore, Md. 2004 Mar;39(3):826-34.

[10] Donato F, Gelatti U, Limina RM, Fattovich G. Southern Europe as an example of interaction between various environmental factors: a systematic review of the epidemiologic evidence. Oncogene. 2006 Jun 26;25(27):3756-70.

[11] El-Serag HB. Epidemiology of hepatocellular carcinoma in USA. Hepatol Res. 2007 Sep;37 Suppl 2:S88-94. 
[12] El-Serag HB, Rudolph KL. Hepatocellular carcinoma: epidemiology and molecular carcinogenesis. Gastroenterology. 2007 Jun;132(7):2557-76.

[13] El-Serag HB. Hepatocellular carcinoma: recent trends in the United States. Gastroenterology. 2004 Nov;127(5 Suppl 1):S27-34.

[14] El-Serag HB, Mason AC. Rising incidence of hepatocellular carcinoma in the United States. The New England journal of medicine. 1999 Mar $11 ; 340(10): 745-50$.

[15] Gallus S, Bertuzzi M, Tavani A, Bosetti C, Negri E, La Vecchia C, et al. Does coffee protect against hepatocellular carcinoma? British journal of cancer. 2002 Oct 21;87(9):956-9.

[16] Inoue M, Yoshimi I, Sobue T, Tsugane S. Influence of coffee drinking on subsequent risk of hepatocellular carcinoma: a prospective study in Japan. Journal of the National Cancer Institute. 2005 Feb 16;97(4):293-300.

[17] Kurozawa Y, Ogimoto I, Shibata A, Nose T, Yoshimura T, Suzuki H, et al. Coffee and risk of death from hepatocellular carcinoma in a large cohort study in Japan. British journal of cancer. 2005 Sep 5;93(5):607-10.

[18] Huang Y, Boynton RF, Blount PL, Silverstein RJ, Yin J, Tong Y, et al. Loss of heterozygosity involves multiple tumor suppressor genes in human esophageal cancers. Cancer research. 1992 Dec 1;52(23):6525-30.

[19] Contran RS, Kumar V, Collins T. Neoplasia. In: Contran RS, Kumar V, Collins T, eds. Robbins: Patologia Estrutural e Funcional

6ed. Philadelphia, PA: WB Sounders Company 2000:233-95.

[20] Tokino T, Nakamura Y. The role of p53-target genes in human cancer. Critical reviews in oncology/hematology. 2000 Jan;33(1):1-6.

[21] Kubbutat $\mathrm{MH}$, Vousden $\mathrm{KH}$. Keeping an old friend under control: regulation of p53 stability. Molecular medicine today. 1998 Jun;4(6):250-6.

[22] Vogelstein B, Kinzler KW. p53 function and dysfunction. Cell. 1992 Aug $21 ; 70(4): 523-6$.

[23] Oren M. Regulation of the p53 tumor suppressor protein. The Journal of biological chemistry. 1999 Dec 17;274(51):36031-4.

[24] Alves VA, Nita ME, Carrilho FJ, Ono-Nita SK, Wakamatsu A, Lehrbach DM, et al. p53 immunostaining pattern in Brazilian patients with hepatocellular carcinoma. Revista do Instituto de Medicina Tropical de Sao Paulo. 2004 JanFeb;46(1):25-31. 
[25] Tolbert D, Fenoglio-Preiser C, Noffsinger A, De Voe G, MacDonald J, Benedetti $\mathrm{J}$, et al. The relation of p53 gene mutations to gastric cancer subsite and phenotype. Cancer Causes Control. 1999 Jun;10(3):227-31.

[26] IARC TP53 Database. [cited; Available from: http://www-p53.iarc.fr

[27] Jackson PE, Kuang SY, Wang JB, Strickland PT, Munoz A, Kensler TW, et al. Prospective detection of codon 249 mutations in plasma of hepatocellular carcinoma patients. Carcinogenesis. 2003 Oct;24(10):1657-63.

[28] Kirk GD, Camus-Randon AM, Mendy M, Goedert JJ, Merle P, Trepo C, et al. Ser-249 p53 mutations in plasma DNA of patients with hepatocellular carcinoma from The Gambia. Journal of the National Cancer Institute. 2000 Jan 19;92(2):148-53.

[29] Turner PC, Sylla A, Kuang SY, Marchant CL, Diallo MS, Hall AJ, et al. Absence of TP53 codon 249 mutations in young Guinean children with high aflatoxin exposure. Cancer Epidemiol Biomarkers Prev. 2005 Aug;14(8):2053-5.

[30] Stern MC, Umbach DM, Yu MC, London SJ, Zhang ZQ, Taylor JA. Hepatitis B, aflatoxin B(1), and p53 codon 249 mutation in hepatocellular carcinomas from Guangxi, People's Republic of China, and a meta-analysis of existing studies. Cancer Epidemiol Biomarkers Prev. 2001 Jun;10(6):617-25.

[31] Staib F, Hussain SP, Hofseth LJ, Wang XW, Harris CC. TP53 and liver carcinogenesis. Human mutation. 2003 Mar;21(3):201-16.

[32] Hussain SP, Amstad P, Raja K, Sawyer M, Hofseth L, Shields PG, et al. Mutability of p53 hotspot codons to benzo(a)pyrene diol epoxide (BPDE) and the frequency of p53 mutations in nontumorous human lung. Cancer research. 2001 Sep 1;61(17):6350-5.

[33] Navas SA, Sabino M, Rodriguez-Amaya DB. Aflatoxin $M(1)$ and ochratoxin $A$ in a human milk bank in the city of Sao Paulo, Brazil. Food additives and contaminants. 2005 May;22(5):457-62.

[34] Yu Y, Wan S, Tan P, Wan X, Miao Z. [Study on determination of aflatoxins B1, B2, G1 and G2 in peanuts using OASIS HLB cartridges with postcolumn derivatization HPLC and fluorescence detection]. Se $\mathrm{pu}=$ Chinese journal of chromatography / Zhongguo hua xue hui. 2004 Nov;22(6):658.

[35] Yu MC, Yuan JM. Environmental factors and risk for hepatocellular carcinoma. Gastroenterology. 2004 Nov;127(5 Suppl 1):S72-8. 
[36] Smela ME, Currier SS, Bailey EA, Essigmann JM. The chemistry and biology of aflatoxin $B(1)$ : from mutational spectrometry to carcinogenesis. Carcinogenesis. $2001 \mathrm{Apr} ; 22(4): 535-45$.

[37] Smela ME, Hamm ML, Henderson PT, Harris CM, Harris TM, Essigmann $\mathrm{JM}$. The aflatoxin $\mathrm{B}(1)$ formamidopyrimidine adduct plays a major role in causing the types of mutations observed in human hepatocellular carcinoma. Proceedings of the National Academy of Sciences of the United States of America. 2002 May 14;99(10):6655-60.

[38] Bennett JW, Klich M. Mycotoxins. Clinical microbiology reviews. 2003 Jul;16(3):497-516.

[39] Groopman JD, Wang JS, Scholl P. Molecular biomarkers for aflatoxins: from adducts to gene mutations to human liver cancer. Canadian journal of physiology and pharmacology. 1996 Feb;74(2):203-9.

[40] Tiemersma EW, Omer RE, Bunschoten A, van't Veer P, Kok FJ, Idris MO, et al. Role of genetic polymorphism of glutathione-S-transferase T1 and microsomal epoxide hydrolase in aflatoxin-associated hepatocellular carcinoma. Cancer Epidemiol Biomarkers Prev. 2001 Jul;10(7):785-91.

[41] Moncada C. Aductos, mecanismos patogénicos. Gastr Latinoam. 2001;1(13):37-9.

[42] Puisieux A, Lim S, Groopman J, Ozturk M. Selective targeting of p53 gene mutational hotspots in human cancers by etiologically defined carcinogens. Cancer research. 1991 Nov 15;51(22):6185-9.

[43] Denissenko MF, Cahill J, Koudriakova TB, Gerber N, Pfeifer GP. Quantitation and mapping of aflatoxin B1-induced DNA damage in genomic DNA using aflatoxin B1-8,9-epoxide and microsomal activation systems. Mutation research. 1999 Apr 6;425(2):205-11.

[44] Guengerich FP, Johnson WW, Shimada T, Ueng YF, Yamazaki H, Langouet S. Activation and detoxication of aflatoxin B1. Mutation research. 1998 Jun 18;402(1-2):121-8.

[45] Roebuck BD, Curphey TJ, Li Y, Baumgartner KJ, Bodreddigari S, Yan J, et al. Evaluation of the cancer chemopreventive potency of dithiolethione analogs of oltipraz. Carcinogenesis. 2003 Dec;24(12):1919-28.

[46] Habib SL, Said B, Awad AT, Mostafa MH, Shank RC. Novel adenine adducts, N7-guanine-AFB1 adducts, and p53 mutations in patients with schistosomiasis and aflatoxin exposure. Cancer detection and prevention. 2006;30(6):491-8. 
[47] Resolução RDC numero 274, 15/10/2002. Diário Oficial da União 2002.

[48] Agencia Nacional de Vigilância Sanitária. [cited 15/01/2007]; Available from: http://www.anvisa.gov.br/inspecao/alimentos/interditados.pdf

[49] Sabino M, Prado G, Inomata El, Pedroso Mde O, Garcia RV. Natural occurrence of aflatoxins and zearalenone in maize in Brazil. Part II. Food additives and contaminants. 1989 Jul-Sep;6(3):327-31.

[50] Kim CM, Koike K, Saito I, Miyamura T, Jay G. HBx gene of hepatitis B virus induces liver cancer in transgenic mice. Nature. 1991 May 23;351(6324):317-20.

[51] Su F, Schneider RJ. Hepatitis B virus HBx protein activates transcription factor NF-kappaB by acting on multiple cytoplasmic inhibitors of rel-related proteins. Journal of virology. $1996 \mathrm{Jul} ; 70(7): 4558-66$.

[52] Hosono S, Chou MJ, Lee CS, Shih C. Infrequent mutation of p53 gene in hepatitis B virus positive primary hepatocellular carcinomas. Oncogene. 1993 Feb;8(2):491-6.

[53] Qu JH, Zhu MH, Lin J, Ni CR, Li FM, Zhu Z, et al. Effects of hepatitis B virus on p53 expression in hepatoma cell line SMMU-7721. World J Gastroenterol. 2005 Oct 21;11(39):6212-5.

[54] Lunn RM, Zhang YJ, Wang LY, Chen CJ, Lee PH, Lee CS, et al. p53 mutations, chronic hepatitis $B$ virus infection, and aflatoxin exposure in hepatocellular carcinoma in Taiwan. Cancer research. 1997 Aug 15;57(16):3471-7.

[55] Kirk GD, Lesi OA, Mendy M, Szymanska K, Whittle H, Goedert JJ, et al. 249(ser) TP53 mutation in plasma DNA, hepatitis B viral infection, and risk of hepatocellular carcinoma. Oncogene. 2005 Sep 1;24(38):5858-67.

[56] Carrilho FJ, Alves VAF, Mello ES, Vezozzo DP. Carcinoma Hepatocelular. In: Gayotto LCC, Alves VAF, eds. Doenças do Fígado e Vías Biliares. 1 ed. São Paulo: Editora Atheneu 2001:997-1015.

[57] Soini Y, Chia SC, Bennett WP, Groopman JD, Wang JS, DeBenedetti VM, et al. An aflatoxin-associated mutational hotspot at codon 249 in the p53 tumor suppressor gene occurs in hepatocellular carcinomas from Mexico. Carcinogenesis. 1996 May;17(5):1007-12.

[58] Rodriguez DB, Sabino M. Mycotoxin reasearch in Brazil: the last decade in review. Brazilian Jourbal of Microbiology. 2002;33:1-11. 
[59] Kimbi GC, Kew MC, Yu MC, Arakawa K, Hodkinson J. 249ser p53 mutation in the serum of black southern African patients with hepatocellular carcinoma. Journal of gastroenterology and hepatology. 2005 Aug;20(8):118590.

[60] Huang XH, Sun LH, Lu DD, Sun Y, Ma LJ, Zhang XR, et al. Codon 249 mutation in exon 7 of p53 gene in plasma DNA: maybe a new early diagnostic marker of hepatocellular carcinoma in Qidong risk area, China. World J Gastroenterol. 2003 Apr;9(4):692-5.

[61] [cited; Available from: http://www-p53.iarc.fr/Graph.asp

[62] Kubicka S, Trautwein C, Schrem H, Tillmann H, Manns M. Low incidence of p53 mutations in European hepatocellular carcinomas with heterogeneous mutation as a rare event. Journal of hepatology. 1995 Oct;23(4):412-9.

[63] Hoque A, Patt YZ, Yoffe B, Groopman JD, Greenblatt MS, Zhang YJ, et al. Does aflatoxin B1 play a role in the etiology of hepatocellular carcinoma in the United States? Nutrition and cancer. 1999;35(1):27-33.

[64] Goldblum JR, Bartos RE, Carr KA, Frank TS. Hepatitis B and alterations of the p53 tumor suppressor gene in hepatocellular carcinoma. The American journal of surgical pathology. $1993 \mathrm{Dec} ; 17(12): 1244-51$.

[65] Garcia S, Heredia N. Mycotoxins in Mexico: epidemiology, management, and control strategies. Mycopathologia. 2006 Sep;162(3):255-64.

[66] Coursaget P, Depril N, Chabaud M, Nandi R, Mayelo V, LeCann P, et al. High prevalence of mutations at codon 249 of the p53 gene in hepatocellular carcinomas from Senegal. British journal of cancer. 1993 Jun;67(6):1395-7.

[67] Ponchel F, Puisieux A, Tabone E, Michot JP, Froschl G, Morel AP, et al. Hepatocarcinoma-specific mutant p53-249ser induces mitotic activity but has no effect on transforming growth factor beta 1-mediated apoptosis. Cancer research. 1994 Apr 15;54(8):2064-8.

[68] Wang XW, Gibson MK, Vermeulen W, Yeh H, Forrester K, Sturzbecher $\mathrm{HW}$, et al. Abrogation of $\mathrm{p53}$-induced apoptosis by the hepatitis $\mathrm{B}$ virus $\mathrm{X}$ gene. Cancer research. 1995 Dec 15;55(24):6012-6.

[69] Forrester K, Lupold SE, Ott VL, Chay CH, Band V, Wang XW, et al. Effects of p53 mutants on wild-type p53-mediated transactivation are cell type dependent. Oncogene. 1995 Jun 1;10(11):2103-11. 
[70] Oda T, Tsuda H, Scarpa A, Sakamoto M, Hirohashi S. p53 gene mutation spectrum in hepatocellular carcinoma. Cancer research. 1992 Nov 15;52(22):6358-64.

[71] Ng IO, Chung LP, Tsang SW, Lam CL, Lai EC, Fan ST, et al. p53 gene mutation spectrum in hepatocellular carcinomas in Hong Kong Chinese. Oncogene. 1994 Mar;9(3):985-90.

[72] Ng IO, Srivastava G, Chung LP, Tsang SW, Ng MM. Overexpression and point mutations of p53 tumor suppressor gene in hepatocellular carcinomas in Hong Kong Chinese people. Cancer. 1994 Jul 1;74(1):30-7.

[73] Greer CE, Lund JK, Manos MM. PCR amplification from paraffinembedded tissues: recommendations on fixatives for long-term storage and prospective studies. PCR methods and applications. 1991 Aug;1(1):46-50.

[74] Lehmann $U$, Kreipe $H$. Real-time PCR analysis of DNA and RNA extracted from formalin-fixed and paraffin-embedded biopsies. Methods (San Diego, Calif. 2001 Dec;25(4):409-18. 
8 ANEXOS - 8 ANEXOS 
1. Comparação entre as amostras de CHC do HC-FMUSP e do HAOC

A comparação das amostras recebidas do DAP - HCFMUSP e do CICAP _ HAOC está descrita abaixo.

\begin{tabular}{cccc}
\hline & HC-FMUSP & HAOC & $\mathbf{p}$ \\
\hline Casuística & 51 amostras & 23 amostras & - \\
Idade média (anos) & $50,28( \pm 18,5)$ & $61,82( \pm 11,4)$ & 0,007 \\
Mulheres & 17 & 4 & 0,12 \\
Presença de cirrose & 31 & 18 & 0,141 \\
Tamanho do tumor & 8,08 & 3,22 & 0,0015 \\
Tumor Grau 4 & 7 & 2 & 0,4 \\
Tumor Grau 3 & 26 & 8 & 0,14 \\
Tumor Grau 2 & 13 & 12 & 0,024 \\
Tumor Grau 1 & 0 & 1 & - \\
249Ser & 17 & 4 & 0,12 \\
Presença de VHB & 11 & 2 & 0,15 \\
\hline
\end{tabular}




\section{Distribuição das 748 mutações do TP53 descritas no CHC}

\begin{tabular}{ccc}
\hline $\begin{array}{c}\text { Número do } \\
\text { Códon }\end{array}$ & Numero de Mutações & \multicolumn{1}{c}{$\%$} \\
\hline 35 & 1 & 0.13368983957219252 \\
56 & 1 & 0.13368983957219252 \\
62 & 1 & 0.13368983957219252 \\
68 & 3 & 0.40106951871657753 \\
73 & 1 & 0.13368983957219252 \\
100 & 1 & 0.13368983957219252 \\
106 & 2 & 0.26737967914438504 \\
110 & 3 & 0.40106951871657753 \\
111 & 3 & 0.40106951871657753 \\
118 & 1 & 0.13368983957219252 \\
130 & 2 & 0.26737967914438504 \\
131 & 5 & 0.6684491978609626 \\
132 & 2 & 0.26737967914438504 \\
133 & 3 & 0.40106951871657753 \\
135 & 3 & 0.40106951871657753 \\
136 & 1 & 0.13368983957219252 \\
137 & 2 & 0.26737967914438504 \\
138 & 1 & 0.13368983957219252 \\
139 & 2 & 0.26737967914438504 \\
140 & 1 & 0.13368983957219252 \\
141 & 3 & 0.40106951871657753 \\
143 & 1 & 0.13368983957219252 \\
144 & 1 & 0.13368983957219252 \\
145 & 1 & 0.13368983957219252 \\
146 & 1 & 0.13368983957219252 \\
147 & 1 & 0.13368983957219252 \\
151 & 2 & 0.26737967914438504 \\
152 & 3 & 0.40106951871657753 \\
154 & 1 & 0.5347593582887701 \\
155 & 1 & 0.13368983957219252 \\
156 & 0.13368983957219252 \\
157 & 1 & 0.40106951871657753 \\
158 & 14.705882352941100 \\
159 & 0.40106951871657753 \\
161 & 1 & 0.26737967914438504 \\
162 & 1 &
\end{tabular}




\begin{tabular}{|c|c|c|}
\hline 163 & 6 & 0.8021390374331551 \\
\hline 164 & 2 & 0.26737967914438504 \\
\hline 166 & 15 & 20.053475935828800 \\
\hline 167 & 1 & 0.13368983957219252 \\
\hline 168 & 1 & 0.13368983957219252 \\
\hline 170 & 1 & 0.13368983957219252 \\
\hline 171 & 2 & 0.26737967914438504 \\
\hline 172 & 3 & 0.40106951871657753 \\
\hline 173 & 1 & 0.13368983957219252 \\
\hline 174 & 5 & 0.6684491978609626 \\
\hline 175 & 12 & 16.042780748663100 \\
\hline 176 & 9 & 12.032085561497300 \\
\hline 177 & 2 & 0.26737967914438504 \\
\hline 179 & 7 & 0.9358288770053476 \\
\hline 181 & 1 & 0.13368983957219252 \\
\hline 184 & 3 & 0.40106951871657753 \\
\hline 187 & 1 & 0.13368983957219252 \\
\hline 189 & 3 & 0.40106951871657753 \\
\hline 192 & 5 & 0.6684491978609626 \\
\hline 193 & 5 & 0.6684491978609626 \\
\hline 194 & 2 & 0.26737967914438504 \\
\hline 195 & 2 & 0.26737967914438504 \\
\hline 196 & 3 & 0.40106951871657753 \\
\hline 197 & 1 & 0.13368983957219252 \\
\hline 198 & 2 & 0.26737967914438504 \\
\hline 199 & 1 & 0.13368983957219252 \\
\hline 200 & 1 & 0.13368983957219252 \\
\hline 204 & 2 & 0.26737967914438504 \\
\hline 205 & 3 & 0.40106951871657753 \\
\hline 206 & 1 & 0.13368983957219252 \\
\hline 208 & 1 & 0.13368983957219252 \\
\hline 210 & 2 & 0.26737967914438504 \\
\hline 211 & 1 & 0.13368983957219252 \\
\hline 213 & 6 & 0.8021390374331551 \\
\hline 214 & 5 & 0.6684491978609626 \\
\hline 215 & 5 & 0.6684491978609626 \\
\hline 216 & 2 & 0.26737967914438504 \\
\hline 217 & 1 & 0.13368983957219252 \\
\hline 218 & 1 & 0.13368983957219252 \\
\hline 220 & 10 & 13.368983957219200 \\
\hline 221 & 3 & 0.40106951871657753 \\
\hline
\end{tabular}




\begin{tabular}{|c|c|c|}
\hline 226 & 2 & 0.26737967914438504 \\
\hline 227 & 1 & 0.13368983957219252 \\
\hline 230 & 1 & 0.13368983957219252 \\
\hline 232 & 2 & 0.26737967914438504 \\
\hline 235 & 2 & 0.26737967914438504 \\
\hline 236 & 5 & 0.6684491978609626 \\
\hline 237 & 2 & 0.26737967914438504 \\
\hline 238 & 4 & 0.5347593582887701 \\
\hline 239 & 7 & 0.9358288770053476 \\
\hline 240 & 1 & 0.13368983957219252 \\
\hline 241 & 6 & 0.8021390374331551 \\
\hline 242 & 10 & 13.368983957219200 \\
\hline 243 & 3 & 0.40106951871657753 \\
\hline 244 & 14 & 18.716577540106900 \\
\hline 245 & 9 & 12.032085561497300 \\
\hline 246 & 5 & 0.6684491978609626 \\
\hline 247 & 3 & 0.40106951871657753 \\
\hline 248 & 15 & 20.053475935828800 \\
\hline 249 & 248 & 33.155080213903700 \\
\hline 250 & 4 & 0.5347593582887701 \\
\hline 251 & 16 & 21.390374331550800 \\
\hline 252 & 1 & 0.13368983957219252 \\
\hline 254 & 1 & 0.13368983957219252 \\
\hline 255 & 2 & 0.26737967914438504 \\
\hline 257 & 2 & 0.26737967914438504 \\
\hline 258 & 7 & 0.9358288770053476 \\
\hline 259 & 2 & 0.26737967914438504 \\
\hline 260 & 1 & 0.13368983957219252 \\
\hline 262 & 1 & 0.13368983957219252 \\
\hline 265 & 1 & 0.13368983957219252 \\
\hline 266 & 6 & 0.8021390374331551 \\
\hline 267 & 3 & 0.40106951871657753 \\
\hline 270 & 1 & 0.13368983957219252 \\
\hline 271 & 3 & 0.40106951871657753 \\
\hline 272 & 6 & 0.8021390374331551 \\
\hline 273 & 31 & 4.144385026737960 \\
\hline 274 & 5 & 0.6684491978609626 \\
\hline 75 & 5 & 0.6684491978609626 \\
\hline 276 & 1 & 0.13368983957219252 \\
\hline 277 & 1 & 0.13368983957219252 \\
\hline 278 & 5 & 0.6684491978609626 \\
\hline
\end{tabular}




\begin{tabular}{lll}
280 & 7 & 0.9358288770053476 \\
281 & 5 & 0.6684491978609626 \\
282 & 7 & 0.9358288770053476 \\
283 & 2 & 0.26737967914438504 \\
285 & 6 & 0.8021390374331551 \\
286 & 8 & 10.695187165775400 \\
287 & 2 & 0.26737967914438504 \\
288 & 2 & 0.26737967914438504 \\
291 & 1 & 0.13368983957219252 \\
292 & 1 & 0.13368983957219252 \\
294 & 2 & 0.26737967914438504 \\
296 & 1 & 0.13368983957219252 \\
298 & 2 & 0.26737967914438504 \\
300 & 1 & 0.13368983957219252 \\
305 & 1 & 0.13368983957219252 \\
306 & 2 & 0.26737967914438504 \\
308 & 1 & 0.13368983957219252 \\
314 & 1 & 0.13368983957219252 \\
317 & 1 & 0.13368983957219252 \\
319 & 1 & 0.13368983957219252 \\
323 & 1 & 0.13368983957219252 \\
324 & 1 & 0.13368983957219252 \\
330 & 2 & 0.26737967914438504 \\
337 & 3 & 0.40106951871657753 \\
339 & 2 & 0.26737967914438504 \\
342 & 6 & 0.8021390374331551 \\
\hline
\end{tabular}




\section{Dados dos Pacientes CHC}

\begin{tabular}{cccccccccc}
\hline Caso & & & \multicolumn{7}{c}{ Tamanho } \\
CHC & Idade & Sexo & Cirrose & Grau & $\begin{array}{c}\text { Tumor } \\
\text { (cm) }\end{array}$ & $\begin{array}{c}\text { Invasão } \\
\text { Vascular }\end{array}$ & Etiologia & 249Ser & VHB \\
\hline 1 & 61 & 0 & 0 & 2 & 9 & 0 & na & 0 & 0 \\
2 & 55 & 1 & 0 & 4 & 12.5 & 1 & 2 & 1 & 1 \\
3 & 7 & 1 & 0 & 4 & 0,5 & 0 & 7 & 0 & 0 \\
4 & 11 & 1 & 0 & 2 & 4 & 0 & 2 & 0 & 0 \\
5 & 76 & 1 & 0 & 2 & 9 & 0 & 2 & 0 & 0 \\
6 & 42 & 1 & 0 & 2 & 1.0 & 1 & 7 & 1 & 0 \\
7 & na & 1 & 1 & 3 & 10 & 0 & 7 & 1 & 0 \\
8 & 28 & 0 & 0 & 3 & 9.0 & 1 & 2 & 0 & 0 \\
9 & 62 & 1 & 1 & 2 & 4.0 & 0 & 2 & 1 & 1 \\
10 & 64 & 1 & 1 & 3 & 2.3 & 0 & 1 & 0 & 0 \\
11 & 62 & 1 & 1 & 4 & 13,5 & 1 & na & 1 & 0 \\
12 & 65 & 1 & 1 & 2 & 1.5 & 0 & 1 & 0 & 0 \\
13 & 34 & 0 & 0 & 3 & 12 & 0 & na & 0 & 0 \\
14 & 66 & 1 & 1 & 3 & 15 & 1 & 4 & 0 & 0 \\
15 & 73 & 1 & 1 & 2 & 4 & 1 & 1 & 0 & 0 \\
16 & 52 & 1 & 1 & 2 & 1.5 & 0 & 1 & 0 & 0 \\
17 & 64 & 0 & 1 & 3 & 3 & 0 & 7 & 0 & 0 \\
18 & 62 & 0 & 1 & 3 & 3 & 0 & 1 & 0 & 0 \\
19 & 52 & 1 & 1 & 3 & 7 & 1 & 1 & 0 & 0 \\
20 & 18 & 1 & 1 & 3 & 2.5 & 0 & 7 & 0 & 0 \\
21 & 64 & 1 & 1 & 2 & na & 0 & 1 & 1 & 0 \\
22 & 37 & 0 & 1 & 4 & na & 1 & 2 & 0 & 1 \\
23 & 48 & 1 & 1 & 3 & 3 & 0 & 5 & 1 & 0 \\
24 & 53 & 0 & 1 & 3 & 2.5 & 0 & 1 & 0 & 1 \\
25 & 12 & 1 & 0 & 4 & 13 & 1 & 7 & 0 & 0 \\
26 & 41 & 1 & 1 & 4 & 20 & 1 & 1 & 1 & 0 \\
27 & 54 & 1 & 1 & 3 & 20 & 1 & 2 & 1 & 0 \\
28 & 66 & 0 & 0 & 3 & 11 & 1 & na & 0 & 0 \\
29 & 55 & 1 & 1 & 2 & 1.7 & 0 & 3 & 1 & 1 \\
30 & 58 & 1 & 0 & 2 & 13 & 1 & 7 & 0 & 0 \\
31 & 58 & 0 & 1 & 3 & na & 0 & na & 1 & 0 \\
32 & 59 & 1 & 0 & 2 & 5 & 0 & na & 0 & 0 \\
33 & 21 & 1 & 1 & 3 & 18 & 1 & 2 & 1 & 0 \\
34 & 39 & 1 & 1 & 3 & 3 & 0 & 1 & 0 & 0 \\
35 & 64 & 0 & 0 & 3 & 3 & 1 & 1 & 0 & 0 \\
36 & 17 & 0 & 0 & 2 & 17 & 1 & 1 & 0 & 0 \\
37 & 39 & 1 & 0 & 2 & 23 & 0 & 7 & 1 & 0 \\
38 & 64 & 0 & 1 & 4 & 3.0 & 0 & 1 & 1 & 0 \\
39 & 24 & 0 & 0 & 2 & 24 & 1 & na & 0 & 0
\end{tabular}




\begin{tabular}{|c|c|c|c|c|c|c|c|c|c|}
\hline 40 & 50 & 0 & 1 & 3 & 3.2 & 1 & 2 & 0 & 1 \\
\hline 41 & 69 & 0 & 0 & 3 & 6.4 & 1 & 7 & 0 & 0 \\
\hline 42 & 67 & 1 & 1 & 3 & 16 & 0 & 2 & 1 & 1 \\
\hline 43 & 80 & 1 & 1 & 2 & 2.3 & 0 & 1 & 0 & 0 \\
\hline 44 & 30 & 1 & 0 & 2 & 16 & 0 & 2 & 0 & 1 \\
\hline 45 & 54 & 1 & 1 & 3 & 3.0 & 1 & 2 & 0 & 1 \\
\hline 46 & 80 & 0 & 1 & 3 & 4.0 & 1 & 1 & 0 & 0 \\
\hline 47 & 45 & 1 & 0 & 3 & 7.0 & 1 & 3 & 0 & 1 \\
\hline 48 & 54 & 1 & 1 & 3 & 4.0 & 0 & 1 & 0 & 0 \\
\hline 49 & 49 & 1 & 1 & 3 & na & 1 & 3 & 0 & 1 \\
\hline 50 & 69 & 0 & 0 & 3 & 12 & 1 & na & 1 & 0 \\
\hline 51 & 49 & 1 & 1 & 2 & 1.8 & 0 & 1 & 1 & 0 \\
\hline 52 & na & na & 1 & na & 2.0 & 1 & na & na & $\mathrm{Na}$ \\
\hline 53 & 74 & 1 & 1 & 2 & 5.9 & 1 & na & 0 & 0 \\
\hline 54 & 67 & 1 & 1 & 2 & 2.8 & 0 & na & 0 & 0 \\
\hline 55 & 46 & 1 & 1 & 2 & 4 & 1 & na & 0 & 0 \\
\hline 56 & 70 & 0 & 1 & 2 & 2 & 0 & 1 & 0 & 0 \\
\hline 57 & na & na & 0 & na & na & na & na & na & $\mathrm{Na}$ \\
\hline 58 & na & na & 0 & 3 & 3.2 & 1 & 4 & na & $\mathrm{Na}$ \\
\hline 59 & 55 & 1 & 0 & 2 & na & 0 & na & 0 & 0 \\
\hline 60 & 71 & 1 & 0 & 3 & 3.5 & 1 & na & 0 & 0 \\
\hline 61 & 58 & 1 & 0 & 3 & 6 & 0 & na & 0 & 0 \\
\hline 62 & 53 & 1 & 1 & 4 & 3 & 1 & 1 & 1 & 0 \\
\hline 63 & 49 & 1 & 1 & 3 & 2.5 & 0 & 2 & 0 & 1 \\
\hline 64 & 48 & 1 & 1 & 2 & 1.2 & 0 & na & 0 & 0 \\
\hline 65 & 48 & 1 & 1 & 2 & 4.5 & 0 & 1 & 0 & 0 \\
\hline 66 & na & 1 & 1 & 4 & 4 & 1 & 4 & na & $\mathrm{Na}$ \\
\hline 67 & na & na & na & na & na & na & na & na & $\mathrm{Na}$ \\
\hline 68 & 35 & 1 & 1 & 2 & 3 & 0 & na & 1 & 0 \\
\hline 69 & 57 & 1 & 1 & 3 & 2 & 0 & 1 & 0 & 0 \\
\hline 70 & 73 & 1 & 1 & 3 & 2.7 & 0 & 2 & 0 & 1 \\
\hline 71 & 77 & 0 & 1 & 2 & 2.1 & 0 & 1 & 0 & 0 \\
\hline 72 & na & na & na & na & na & na & na & na & $\mathrm{Na}$ \\
\hline 73 & 65 & 1 & 1 & 2 & 4 & 1 & 1 & 0 & 0 \\
\hline 74 & 71 & 1 & 1 & 1 & 1,2 & 0 & 1 & 0 & 0 \\
\hline 75 & 77 & 1 & 0 & 3 & na & 1 & na & 0 & 0 \\
\hline 76 & 70 & 0 & 1 & 3 & 1.5 & 1 & 1 & 0 & 0 \\
\hline 77 & 72 & 1 & 0 & 2 & 1.3 & 1 & 1 & 0 & 0 \\
\hline 78 & 63 & 0 & 1 & 2 & 1.6 & 1 & 1 & 0 & 0 \\
\hline 79 & 59 & 1 & 1 & 4 & 11 & 1 & na & 1 & 0 \\
\hline 80 & 64 & 1 & 1 & 3 & 2 & 0 & na & 1 & 0 \\
\hline
\end{tabular}

na $=$ Não avaliado

= Excluído por não apresentar amplificação na PCR 